Portland State University

PDXScholar

1990

\title{
Walter Kempowski's Familienchronik : history and the role of Erziehung
}

\author{
Carla Ann Damiano \\ Portland State University
}

Follow this and additional works at: https://pdxscholar.library.pdx.edu/open_access_etds

Part of the German Literature Commons Let us know how access to this document benefits you.

\section{Recommended Citation}

Damiano, Carla Ann, "Walter Kempowski's Familienchronik : history and the role of Erziehung" (1990). Dissertations and Theses. Paper 3993.

https://doi.org/10.15760/etd.5877

This Thesis is brought to you for free and open access. It has been accepted for inclusion in Dissertations and Theses by an authorized administrator of PDXScholar. Please contact us if we can make this document more accessible: pdxscholar@pdx.edu. 
AN ABSTRACT OF THE THESIS OF Carla Ann Damiano for the

Master of Arts in German presented July 24, 1990.

Title: Walter Kempowski's Familienchronik: History and the Role of Erziehung

APPROVED BY THE MEMBERS OF THE THESIS COMMITTEE:

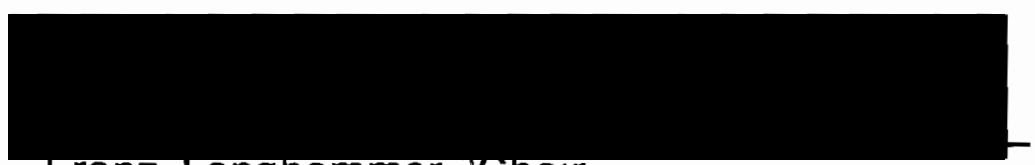

Franz Langnammer, schair

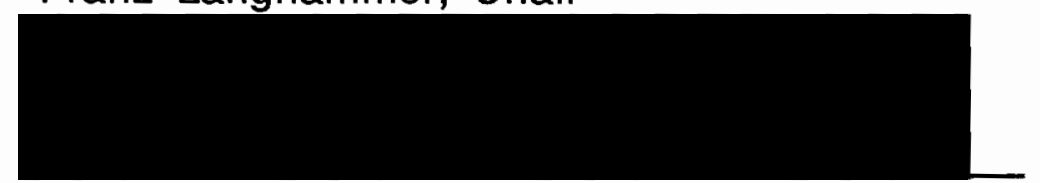

Timm Menke

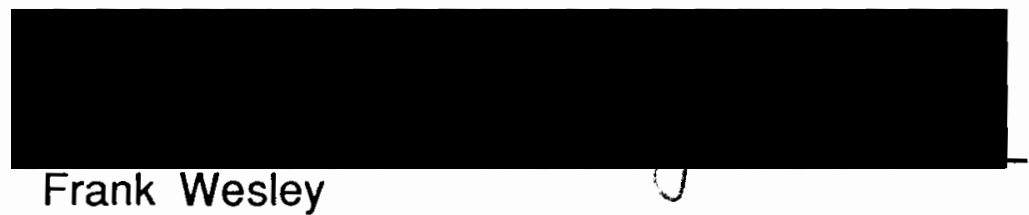

This thesis attempts to prove that Walter Kempowski writes historical fiction. For this reason he should be considered an important 20th century German author. This contention is based on the presence of historical references regarding the topic of Erziehung in the Kempowski Familienchronik. 
The Familienchronik is a series of six novels which follow the historical development of the Kempowski family in Germany beginning from the year 1900 and continuing through 1963 . Unique to the novels is that they represent thoughts and actions of the German middle-class spanning these years. The author does not attempt to use hindsight as a means of intervention in order to expose past wrong-doings. Rather, he lets these wrong-doings speak for themselves -- they are manifested in the routine activities of bourgeois life.

Chapter 1 of the thesis introduces Kempowski as well as his works and discusses various critics opinions regarding the author's strengths and weaknesses. In addition, it defines the term Erziehung as it relates specifically to this topic.

Chapter II explores the concept of history, how the historian goes about writing history and then attempts to draw a parallel between Kempowski's manner of recording past events with that of the historian. It further contends that the Familienchronik has value both as an historical novel as well as a social novel.

Chapter III provides the reader with an overview of the German educational system from Bismarck to Hitler. Its function is merely to serve as a point of reference in order to aid in drawing conclusions.

Chapter IV undertakes the study of three selected novels of the Familienchronik -- Aus großer Zeit, Schöne Aussicht and Tadellöser \& Wolff -- to demonstrate how the author graphically depicts the educational systems for each corresponding period in history. The 
objective is to prove that Kempowski elucidates the reader to educational philosophies as well as teaching strategies -- both of which played a role in instilling certain values and belief systems in the German people. These, then, played a role in historical developments.

The thesis concludes by summarizing the above-mentioned points, thus claiming that Walter Kempowski does belong among the major German authors of this century. To believe otherwise is, perhaps, to misinterpret Kempowski's intended message or to indicate that one is not familiar enough with the author's works. 
WALTER KEMPOWSKI'S FAMILIENCHRONIK: HISTORY AND THE ROLE OF ERZIEHUNG

\author{
by \\ CARLA ANN DAMIANO
}

A thesis submitted in partial fulfillment of the requirements for the degree of

\title{
MASTER OF ARTS
}

in

GERMAN

\author{
Portland State University \\ 1990
}


TO THE OFFICE OF GRADUATE STUDIES:

The members of the Committee approve the thesis of

Carla Ann Damiano presented July 24, 1990.

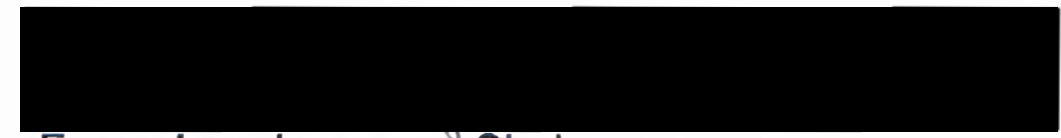

Franz Langhammer, Chair

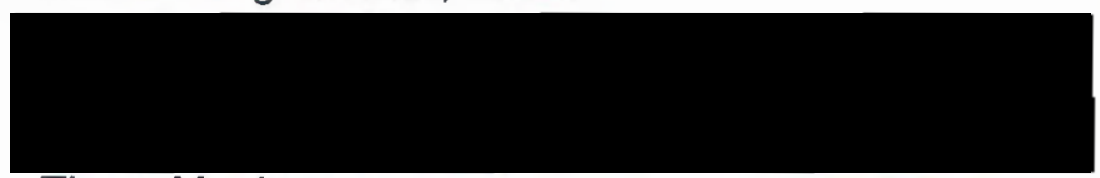

Timm Menke

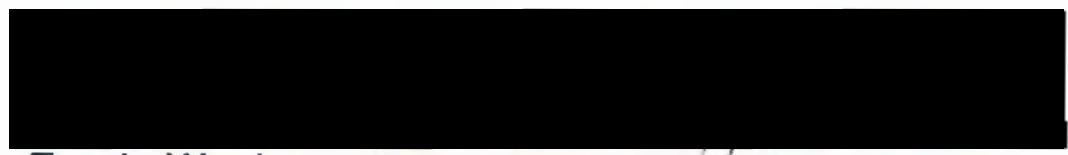

Frank Wesley

APPROVED:

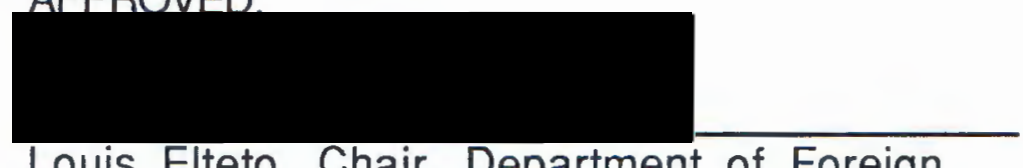

Louis Elteto, Chair, Department of Foreign

Languages and Literatures

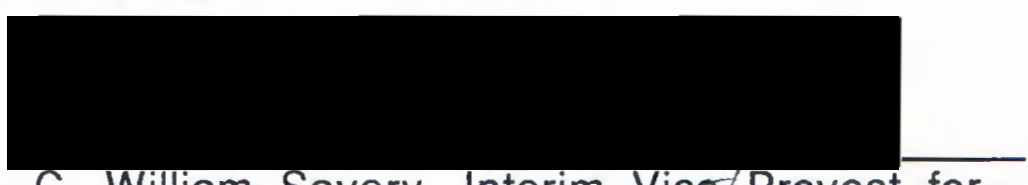

C. William Savery, Interim Vice/Provost for Graduate Studies and Research 


\section{ACKNOWLEDGMENTS}

My thanks go out first and foremost to my parents, who have always remained my supporters and encouragers throughout all my endeavors.

Special acknowledgement is due to Walter Kempowski for suggesting that I write my thesis on his works and for aiding me in acquiring otherwise unobtainable reference materials.

I owe a debt to two friends in particular: to Ralf Genske -- for the countless hours of coffee and discussion during the initial stages of my project -- and to Barry Hunt, who spent painstaking hours patiently wading through my rough drafts.

My warmest gratitude is extended to all of my professors who have helped to guide me in my career as a student of the German language.

Finally, I would like to extend my indebtedness to my advisor, Dr. Franz Langhammer, for his guidance and display of confidence in me and my abilities. 
TABLE OF CONTENTS

PAGE

ACKNOWLEDGEMENTS $\ldots \ldots \ldots \ldots \ldots \ldots \ldots \ldots \ldots \ldots \ldots \ldots \ldots \ldots$ iii

\section{CHAPTER}

I INTRODUCTION $\ldots \ldots \ldots \ldots \ldots \ldots \ldots \ldots \ldots \ldots \ldots$

Meaning of the Term Erziehung ........... 11

Publications ........................ 13

Criticisms of Kempowski's Works . . . . . . . . . 14

II THE GERMAN EDUCATIONAL SYSTEM FROM BISMARCK TO HITLER $\ldots \ldots \ldots \ldots \ldots \ldots \ldots \ldots 26$

Education in Imperial Germany . . . . . . . . . 2 27

Education in the Weimar Republic . . . . . . . . . 29

Education under National Socialism . . . . . . . . 32

III KEMPOWSKI AS HISTORIAN ................. 38

Parallels between Kempowski's Writing Technique and that of an Historian's . . . . . . . . . . . 41

Sources for Kempowski's Works . . . . . . . . . . 43 
Familienchronik: Historical Novel or

Social Novel? . . . . . . . . . . . . . . . . . . . 45

Problems and Pitfalls of Approaching

a Novel Through the Perspektive

of a Social Historian . . . . . . . . . . . . . 49

IV ERZIEHUNG AND HISTORICITY IN THREE NOVELS

OF THE FAMILIENCHRONIK .............53

Aus großer Zeit $(1900-1918) \ldots \ldots . . \ldots . .54$

Schöne Aussicht $(1919-1938) \ldots \ldots \ldots \ldots 70$

Tadellöser \& Wolff $(1939-1945) \ldots . . \ldots . . . .990$

V SUMMARY .................. 103

LIST OF WORKS CONSULTED . . . . . . . . . . . . . . . . . 106 


\section{CHAPTER I}

\section{INTRODUCTION}

This thesis attempts to prove that Walter Kempowski writes historical fiction. For this reason he should be considered an important 20th century German author. This contention is based on the presence of historical references regarding the topic of Erziehung in the Kempowski Familienchronik.

The Familienchronik is a series of six novels which follow the historical development of the Kempowski family in Germany beginning from the year 1900 and continuing through 1963 . Unique to the novels is that they represent thoughts and actions of the German middle-class spanning these years. The author does not attempt to use hindsight as a means of intervention in order to expose past wrong-doings. Rather, he lets these wrong-doings speak for themselves -- they are manifested in the routine activities of bourgeois life.

A study of three selected novels of the Familienchronik -- Aus großer Zeit (1900-1918), Schöne Aussicht (1919-1938) and Tadellöser \& Wolff (1939-1945) -- investigates how the author graphically depicts the educational systems for each corresponding period in history. The objective is to demonstrate that the 
Kempowski texts elucidate the reader to educational philosophies, as well as teaching strategies -- both of which played a role in instilling certain values and belief systems in the German people.

"Kempowski gehört zu den meistgelesenen deutschen Autoren der Gegenwart"1 states Henrich Brockhaus in a 1976 article, while Patricia Haas Stanley writes in 1982: “. . . eine der überraschendsten Begabungen der neueren deutschen Literatur."2 Again in 1990 the author is praised as: ". . . einer der erfolgreichsten westdeutschen Schriftsteller...."3 Notwithstanding his prominence among his peers, many scholars continue to ask: "Who is Walter Kempowski?" There continues to be much discussion such as: Will Kempowski's renown extend beyond his own lifetime, thereby placing him on the list of significant 20th Century German authors? Will his success be limited to the generations of readers who can personally identify with the historical times of his novels? Relatively little scholarly research has been done on the author in comparison with other major 20th Century German literary figures, even though his name is often listed among them.

1 Henrich Brockhaus, "Walter Kempowski: Zeit- und Kultur-Geschichte aus dem Zettelkasten," Proceedings of the Pacific Northwest Council on Foreign Lanquages, 27, ii (1976): 22.

2Bolesch, Cornelia, as quoted in Patricia Haas Stanley, "An Examination of Walter Kempowski's Ein Kapitel für sich." South Atlantic Review 47 (1): Jan 1982, 38 .

${ }^{3}$ Deutschland Nachrichten, 12 Jan 1990: 7. 
Walter Kempowski was born on April 29, 1929 in Rostock, Germany. He was the third of three children born to Karl and Margarethe Kempowski. His father, a ship owner, was a highly respected businessman among his peers. This enabled the family to enjoy the comforts of bourgeois life to the degree that conditions allowed. Walter received his early schooling in Rostock, where, due to circumstances which he explains in an interview with llo von Waltershausen ${ }^{4}$, he was expelled from high school before receiving his diploma. This, of course, made it impossible for him to begin studies at a university and he had no other choice to further his education but to seek a position as an apprentice. With the help of family and friends, he eventually began an apprenticeship in a printery in Rostock. In 1948, at the age of eighteen, he left Rostock for Wiesbaden, hoping to find a better life in the West as the future looked dim for residents of the Russian-occupied East Zone. There he found employment with the Americans working as a clerk in a grocery supply store. "When he returned to Rostock to visit his mother and pick up some belongings, he was arrested by the Russians for having crossed the border illegally and for suspected espionage."5 He had allegedly smuggled bills of lading to the West which showed that the Russians were confiscating goods --

4/lo und Margit von Waltershausen, "Interview: Walter Kempowski," Inter Nationes Kultureller Tonbanddienst, order number 37183: 53

${ }^{5}$ Kane 419. 
supplies intended for the East Zone were in actuality being shipped to the Soviet Union. Kempowski was "tried," found guilty, and sentenced to twenty-five years of forced labor. 6 He served eight years in Bautzen before being granted amnesty and released in 1956. In the same year, following a period of adjustment during which time he lived with his mother in Hamburg, he went to Göttingen, where he completed his yet-unfinished high school diploma and began his studies in pedagogy. There he met his wife, Hildegard Jansen -- also studying to become a teacher. Having received a teaching degree, he returned to northern Germany where he worked as a Landlehrer for 20 years. Since 1981 he has been a guest lecturer at the Universität Oldenburg.

Kempowski's first publication apeared in 1969 under the title Im Block, in which he recounts his eight-year ordeal as a political prisoner in Bautzen. ". . . als ich aus dem Zuchthaus kam, habe ich zunächst einmal den Wunsch gehabt, meine dortigen Erlebnisse niederzuschreiben. . . ."7 $\mathrm{He}$ began collecting material for the book shortly after his release in 1956 but it was not until thirteen years later that he was able to bring it to fruition. His efforts appeared futile, however, for although he found immediate acceptance by

6Here it is important to note that Walter Kempowski was not the only member of the family to be arrested by the Russians for espionage. His brother, Robert, was also arrested on March 8, 1948. Shortly thereafter, their mother was taken into custody as well, on the assumption that she had conspired with them in informing American authorities of Russian activities.

7 Waltershausen 53 . 
some critics, the book did not gain him wide public attention. "What he wanted to sketch were his experiences as a prisoner of the Russian occupation forces from 1948-1956. . . . But in spite of glowing reviews, the book was not a commercial success." 8 Recognition as a prominent writer did not come until 1971 with the publication of Tadellöser \& Wolff.

The author is most widely recognized for the Familienchronik ${ }^{9}$, which deals with the "Auf und $A b$-- Wohl und Wehe"10 of the Kempowski family. The proposed seventh and final volume, which would continue the family history beginning from 1963, has yet to be published. The Familienchronik is most often likened to Thomas Mann's Buddenbrooks. It is considered by some critics a Bildungsroman, while others term it as mere "recollections" of the narrator. Some say that due to the "pointillistic" style of writing, reading a Kempowski novel is like leafing through the pages of a photo album, thus gleaning superficial images of the past.

Among the critics, Kempowski understandably has both friend and foe. Undoubtedly his greatest foe of late is Harald Wieser who

8Patricia Haas Stanley, "An Examination of Walter Kempowski's Ein Kapitel für sich." South Atlantic Review 47 (1): Jan 1982, 38.

${ }^{9}$ The novels of the Familienchronik as they appear in chronological order in the series include: Aus aroßer Zeit(1978); Schöne Aussicht (1981); Iadellöser \& Wolff (1971); Uns gehts ia noch Gold (1972); Ein Kapitel für sich (1975); Herzlich Wilkommen (1984).

10Walter Kempowski, "Die Entfesselungskunst," unpublished essay: 1. (Note: all unpublished Kempowski essays obtained from Dr. Alan Keele, Brigham Young University). 
wrote an article in the German magazine Stern, blatantly accusing the author of plagiarism.11 Notwithstanding this accusation, the author is most often criticized for the following interwoven characteristics which allegedly typify his writing style:

1. "He does not use the sovereign perspective of the present from which to recreate the past, nor does he avail himself of hindsight in order to comment on and evaluate it."12

2. Kempowski's method of writing does not reflect creative initiative.

3. The language in his novels is not elevated.

4. There is little historical validity to his novels.

5. He tends to trivialize the events of the Nazi past.

(These points are further elaborated in section 4 of this chapter).

A large majority of Kempowski readers consists of the generations of those who personally experienced the historical times encompassed in the novels. This fact leads many Kempowski critics to assert that the author's fame will not extend beyond the

11 Harald Wieser, "Der Abschreiber," Stern Magazin. 11 Jan. (1990): 29-34. The former best-seller novel Aus Großer Zeit is the one which drew Kempowski so much negative attention in Wieser's Stern article. Wieser accuses the author of plagiarism -alleging him to have copied five pages from the diary of a former Rostock resident and using them verbatim in his novel. Spiegel journalist Hellmuth Karasek, however, called Wieser's attack "eine unsinnige Literatur-Kampagne." Kempowski, claimed Karasek, was simply exercising dichterische Freiheit as so many have done before him; examples cited are Georg Büchner, Thomas Mann and Alfred Döblin.

12B.M. Kane, "Scenes from Family Life: The Novels of Walter Kempowski," German Life \& Letters 28 (1974-75): 418. 
lifetime of this particular reading audience. One could argue, however, that Kempowski's novels are of historical importance in that they are representative of the life and culture of generations of Germans during particularly crucial periods in their nation's history. If this is true, then the Kempowski novels will maintain their cultural significance indefinately. But rather than labelling the Familienchronik an "historical novel", however, and falling into the trap of taxonomy, one could maintain that Kempowski's novels, in essence, "breathe an historical conscience" into the age they represent. If this assertion were justifiable through careful critical analysis, one could refute the claims of Kempowski's critics.

Based on an unpublished Kempowski essay entitled, "Über die Allgegenwart von Erziehung," this research intends to show that in the realm of Erziehung, Kempowski's Familienchronik yields valuable insights into the historical background of the educational processes in early 20th century Germany. Based on these findings, this research shall then support the claim that Kempowski is indeed a significant 20th century German literary figure.

The time span of the novels includes the years preceding the Nazis' rise to power (1900-1933), the Third Reich period (19331945) and the building of a new nation (1946-1963). I shall examine the role Erziehung played in developing certain attitudes and ideals in German society between 1900-1945. Kempowski writes in the above-mentioned article that there are "zahllose Passagen" in his Familienchronik that deal with Erziehung. One should pay 
particularly close attention to this omnipresent theme. Kempowski demonstrates that this discussion topic is not only of immense personal interest to him, but in addition, played a major role in influencing history.

Kempowski has made it evident in various interviews, essays, etc., that the intention of his novels is to expose the weak links in society -- such as ignorance, apathy, indifference -- which contributed to the rise of national socialism. His hope is that by showing present and future generations what went wrong in the past, history will not repeat itself. He believes to be portraying the actions and reactions of a representative middle-class German family. However, one must beware of mistaking the author's stated intentions for his actual accomplishments. "The problems of mistaking intention for accomplisment and details for facts are similar to the common mistaking of a novel's narrator for the author, or a character's voice for the novelist's."13 On the one hand, it would be advantageous to know what the author considers to be self-evident in his works -- so that there need be no speculation. On the other hand, with this previous insight, the reader approaches the work already biased. There exists, therefore, the impending danger that the reader may simply assume this to be present in the text, rather than forming conclusions through the process of analysis. The question remains: are Kempowski's novels historical because Fiction," History and Theory 22.3 (1983): 238. 
he, the author claims them to be or because historicity is inherent in the text? Dietrich Weber quotes Kempowski's assertion (regarding Tadellöser \& Wolff) that his novels should be categorized as historical fiction:

Ich habe den bürgerlichen Alltag in einem Autoritären Staat gezeigt und die Einsicht beim Leser erzielen wollen, daß zahlreiche charakteristische Züge jenes Bürgertums, das einst Nährboden des Nationalsozialismus war, noch immer bestehen. ${ }^{14}$

Weber follows with Kempowski's statement pertaining to the Familienchronik as a whole:

Wir haben uns bewußt zu machen, daß wir wieder in einer Restaurationszeit leben. Das will ich in meinen Büchern veranschaulichen. Ich will zeigen, wie eine Gesellschaft sich restauriert hat und noch weiter restauriert und wie wenig sie im Grunde aus der Vergangenheit gelernt hat, in der Hoffnung, daß sie etwas mehr nachdenkt und für Korrekturen empfänglicher wird. ${ }^{15}$ (italics added)

One could maintain, then, based on Kempowski's testimony, that the author's Familienchronik serves a didactic role, namely, that one should learn from history. However, it does not suffice to know

${ }^{14}$ Dietrich Weber, "Walter Kempowski," Deutsche Literatur der Gegenwart: in Einzeldarstellung, ed. Dietrich Weber, vol. 2 (Stuttgart: Alfred Kröner Verlag, 1977) 284.

15 Weber 284. 
what the author claims to be self-evident in his novels, which is what literary critics term the "intentional fallacy":

"Reference to the author's supposed purposes or state of
mind in writing a text is held to be a harmful mistake,
because it distracts us to such 'external' matters as the
author's biography, or psychological condition, or
creative process, which we substitute for the proper
critical concern with the 'internal' constitution of the
literary product."1 6

One must instead examine the work as an autonomous entity and regard the author's intentions simply as a point of reference from which to draw conclusions.

Kempowski raises the following questions in his article, "Über die Allgegenwart von Erziehung," to which answers will be sought in the Familienchronik:

1. "Wie war die Erziehung beschaffen, die unsere Eltern genossen und die sie ihrerseits ihren Kindern angedeihen ließen?" and more specifically:

2. "Wie wurden sie auf den Weg gebracht, die Menschen, die das Dritte Reich verursachten und die die Folgen dann erleiden mußten in Gestalt von Tod, Siechtum, Vertreibung oder Gefängnis?"17

16 M.H. Abrams, A Glessary of Literary Terms. 5th ed. (Fortworth: Holt, Rinehart and Winston, Inc., 1985) 85.

17Kempowski, "Erziehung" 1 
In the Familienchronik Kempowski demonstrates how the changes from one political regime to the next, beginning with the Kaiserzeit and extending through the post-WWII period, were reflected through the educational system -- both formal and informal. Ever-changing were the methods, purposes, values and attitudes. What he accomplishes through his novels then, is not simply a repetition of historical facts and dates. Rather, he offers what mere facts and dates cannot -- a look back in time through the perspective of a representative middle-class German family. Through his detailed ("pointillistic") accounts of past events, he attempts to place the reader directly into the life of earlier times. Kempowski recreates the educational system in Germany from a perspective that is not present in traditional history books. In this way, he in essence breathes an historical conscience into the period his novels represent.

\section{MEANING OF THE TERM ERZIEHUNG}

In order to clarify the intention of this project, it is necessary to explain the meaning of Erziehung as it relates to the topic. Erziehung has no single meaning in English. In Kempowski's article entitled, "Über die Allgegenwart von Erziehung," which serves as the cornerstone for this project, the concept of Erziehung connotes various interpretations, as is the author's intention. He suggests that there is not merely one, but rather there are many ways in 
which one learns. These various ways he describes in terms of "learning stations": the classroom, the family dinner table, the street, etc., all of which contribute to the process of one's upbringing. Erziehung is thus a very general concept which may make reference to any of these stations. In accord with Kempowski's understanding of the term is Wahrig's dictionary definition:

Planmäßige und zielvolle Einwirkung auf junge Menschen, um sie mit all ihren Fähigkeiten und Kräften geistig, sittlich und körperlich $\mathrm{zu}$ formen und $\mathrm{zu}$ verantwortungsbewußten und charakterfesten Persönlichkeiten heranzubilden. ${ }^{18}$

English equivalents include such expressions as upbringing, formal schooling, training and raising a child to be well-mannered and polite. To sum up Kempowski's use of the term, Erziehung embodies three concepts:

1. what children learn from their parents

2. what children learn through the process of formal schooling

3. what children learn from their peers.

Kempowski's novels abound with examples of such "stations." However, to clarify and further concentrate the topic, I shall

${ }^{18}$ Gerhard Wahrig, Wahrig_Deutsches Wörterbuch. (München: Mosaik Verlag GMBH, 1986/1987) 438. 
restrict the interpretation of Erziehung to the concept of formal schooling. Formal schooling, then, shall refer specifically to the educational system in Germany during the periods discussed in the Kempowski Familienchronik (1900-1963).

\section{PUBLICATIONS}

Although his success has come most widely from the popularity of the Familienchronik, Kempowski has worked in other areas of publication as well. The first novel for which he gained wide recognition, Iadellöser \& Wolff, was made into a television movie under the same title in 1975. Two later novels also appeared as television movies in the late 1970's under the collective title, Ein Kapitel für sich, ${ }^{19}$ exposing him to an even wider viewing public. And the most recent is a 1990 television movie based on the (to date) last novel of the series, Herzlich Willkommen. In addition, he has written various radio plays -- most of which were published in the early seventies. The Sachbücher, as they have been termed, were written to provide the missing link to the chronicles, as well as to alert the public to Kempowski's awareness of the historical-

19 It is noteworthy that Patricia Haas Stanley claims Kapitel to be the "most impressive segment of the Familienchronik". She offers two reasons in support of her stand: 1) "stylistic sophistication employed for the first time in the series reveals Kempowski's 'Begabungen' as a writer and gives this novel a universal appeal." and 2) "The work is a Bildungsroman in the tradition of Goethe, Keller and Tomas Mann, stylistically influenced, however, by the work of the American, William Faulkner." (see Stanley 38). 
political situation during the years spanned by his novels. These books are a collection of eye-witness accounts of the Hitler period including Haben Sie Hitler gesehen? (1973) and Haben Sie davon gewuBt? (1974) A third book of this series, Immer so durchgemogelt (1974) poses the question: "What do you remember about your school experiences?" In addition, Kempowski has written childrens' books. Examples are Unser Herr Böckelmann (1979) and Kempowskis einfache Fibel (1980).

Kempowskis 1988 novel, Hundstage is a deviation from the established style and subject-matter of his novels. For the first time he is not writing about the Kempowski family saga, nor does the setting allude to a specific historical-political setting.

\section{CRITICISMS OF KEMPOWSKI'S WORKS}

The following points subject Kempowski most frequently to attacks from critics and jeopardize his reputation as an important literary figure of the 20th century. However, for each critic who attacks him on a certain account, there seems to be one to defend him:

1. "He does not use the sovereign perspective of the present from which to recreate the past, nor does he avail himself of hindsight in order to comment on and evaluate it." 20 According to some critics, 
Kempowski does not belong in the same category as other post-WWII authors, because in essence, he idealizes the past. A typical example of such criticism is offered by Weber regarding Tadellöser \& Wolff: ". . . die Perspektive des Hauptzeugen Walter aber bleibt hier wie sonst auf das Bewußtsein zur Zeit des Geschehens beschränkt."21 Kane, however, does not view this as necessarily negative. Her comment regarding Im Block typifies hers, as well as Kempowski's view with relation to the entire Familienchronik: "It is remarkably free of personal, polemical bitterness."22

2. Kempowski's method of writing does not promote creative initiative. Görtz addresses the issue: "Zwar wundert sich die zuständige Kritik über die berserkerhafte Sammlerwut des Schriftstellers Walter Kempowski, mokiert sich gelegentlich auch über seine Zettelkastenseligkeit . . .."23 Readers, as well as critics, are fully aware of his writing method. He spent years collecting information and materials, which have served as the backbone for most of his works. His Zettelkasten, as he has labelled it, is a compilation of notecards: testimonies of eye-witness accounts, personal recollections, newspaper clippings, diaries, imaginative ideas, and photographs. This information is then arranged

\section{Weber 282.}

22 Kane 419.

${ }^{23}$ Franz Josef Görtz, "Walter Kempowski als Historiker," Akzente 3: June 1973, 245. 
chronologically on a bulletin board so that he has a visual image as well as a written image of each chapter.

Kempowskis Arbeitsweise ist das Sammeln und Ordnen. Seine Erinnerungsfragmente setzt er wie Mosaiksteinchen zusammen. Literarische Fotoalben entstehen, die, überscharf im Detail, Bild and Bildchen reihen. Dabei werden die bloßen Fakten durch Anekdoten, Verse, Schlager, Witze, Redensarten angereichert. So erscheint individuelle Lebensgeschichte als Montage aus kollektiven Normen, Sprachmustern, Bewußtseinsformen und Verhaltensweisen. Es wird letztlich keine Autobiographie erzählt, sondern eine Lebensform inventarisiert: ihr Name ist Bourgeoisie.24

Some critics claim he relies too heavily on such material, thus detracting from his individual talent and creativity. It is this seeming lack of creativity which makes it difficult to take him and his works seriously. As Weber explains: "Dokumentation dieser Art ist, wenn man sie an der Kategorie der Geschichtsschreibung mißt, durch Überschuß auf der einen Seite und durch Mangel auf der anderen gekennzeichnet."25

Ingeborg Drewitz appears to be his strongest critic in this respect:

24Norbert Mecklenburg, "Faschismus und Alltag in deutscher Gegenwartsprosa: Kempowski und andere" in Gegenwartsliteratur und Drittes reich: Deutsche Autoren in der Auseinandersetzung mit der Vergangenheit, Ed. Hans Wagener, (Stuttgart: Philipp Reclam jun., 1977) 16. 
Kempowskis Methode der minutiösen Wiedergabe der Details, der Reihung unverknüpfter Erinnerungssplitter, ist jedenfalls so ungewöhnlich, daß sie mit Recht Aufsehen erregt hat. Sie gibt inm die Möglichkeit, kalendarisch anstatt episch zu verfahren, auf Erzählstrukturen zu verzichten, Alltägliches und Einmaliges $z u$ notieren, ohne daß es perspektivisch festgelegt wird, und den Text soweit auszutrocknen, daß er sich wie ein Protokoll liest, notiert von einem, der sich in der Rolle des Zuschauers zurückhält, auch wo es um das eigene Erleben geht. ${ }^{26}$

Spiegel journalist Hellmuth Karasek explicates: "Folgerichtig ist Kempowski von der Literatur-Kritik auch als 'Zettelkasten-Literat,' als eifriger Jäger und Sammler, als Museumsdirektor einer literarischen Ausstellung beschrieben worden."27

Ironic about so much negative attention concerning his mode of writing is that Kempowski has never attempted to conceal it. On the contrary, he talks openly about it. In fact, his eigenwillige Arbeitstechnik has been discussed in such detail that he hesitates to address the issue again. The author's reply to Hage's question of whether or not he would like to expound on his writing technique conveys his attitude toward the subject: "Muß das sein? Man hat jetzt schon soviel über diese Zettelarbeit gesprochen, es widerstrebt mir eigentlich, das nochmal auszuwalzen."28 The

\footnotetext{
26Ingeborg Drewitz, "Prosa aus dem Zettelkasten," Neue Bundschau 84.1 (1973): $\quad 171-2$.
}

27Hellmuth Karasek, "Der Ehrabschreiber," Der Spiegel 15 Jan. 1990: 177. 28 Hage 342. 
author, therefore, does not view his writing technique as extraordinary -- worthy of so much undue attention.

Kempowski's writing technique is neither extraordinary nor unusual. Many authors have created great works of literature employing precisely the same approach. Hellmuth Karasek (in his defense of the alleged plagiarism accounts in the Kempowski novel, Aus großer Zeit) cites many such examples. ${ }^{29}$

3. Kempowski's language is not elevated. His language is neither poetic, sophistocated, nor refined. In most instances it is the spoken language in written form, thus allowing the author to employ many colloquialisms. He often employs expressions and clichés, many of which are clearly dated. They are thus recognizable, perhaps, only to native speakers of German and witnesses of the times represented. This recognition, in part, is what has made Kempowski so celebrated among his readers. The otherwise strong Kempowski critic, Drewitz, even agrees on this point: "Mitlebende dieser Jahre erkennen plötzlich, wie sehr ihre eigenen Erfahrungen zeittypische, generationstypische gewesen sind. . . ."30

To complicate matters with the Familienchronik, Kempowski uses expressions of a family language -- invented by his father, Karl Kempowski, for which the reader needs further information to understand. Examples include such utterances as "Tadellöser \&

29 Karasek 173-181.

${ }^{30}$ Drewitz 172. 
Wolff" or "klare Sache und damit hopp!" Dietrich Weber labels such expressions as ". . . verballhornte oder ironisch verwendete Bildungszitate und Sprichwörter," as well as "privatsprachliche Redensarten."31 This factor proves problematic for potential translators.To date the only novel from the series which has been translated into English is Aus großer Zeit, which does not include as many problem passages. In fact, a translator would be forced to alter the characteristic which places the author in a class all his own -- namely his choice of language.

When confronted with the issue of translation, Kempowski refers to an excerpt from one of the novels which has in fact been translated. Although it does read like an original, it is not a representative example of a problem passage. It still offers no solutions on how to deal with dialect and family language games. The author, however, is not troubled by the question of the translatability of his Familienchronik. He sees an alternative. His attitude is conveyed in a 1972 interview with Volker Hage, "Man kann ja auch Fremdsprachen lernen."32

4. There is little historical validity to Kempowskis' novels. Drewitz comments on his perhaps too "pointillistisch" photo-album style of writing. She maintains that although at times one is given vivid historical information, these references are too few. The 
criticism here is that such details obscure the significance in relation to the overall historical picture the works represent. One gets the impression of leafing through pages of a family photograph album. In keeping with the metaphor of the photo album, the reader sees the details of many individual snapshots clearly but collectively, these images fail to offer a complete picture. Although the following comment was made in reference to the novel Uns geht's ia noch gold, it is well representative of the Familienchronik as a whole. ". . . unverbunden sagen diese Details zu wenig aus über die Situation. . .."33 Drewitz then compares Kempowski with other Kahlschlagliteratur authors representing the Group 47. She states that Kempowski's all too "pointillistic" historical references are in no way comparable to the realism depicted by other such post-war writers, suggesting that the problem may stem from his writing method. She poses the question:

Ist also die Schreibmethode zur Mauer geworden, weil sie der kreativen Spannung nicht mehr adäquat ist? Und versagt die Dokumentation, weil die pointillistische Abschilderung der Oberfläche die Wirklichkeit der Zeit nicht mehr faßt?34

She concludes by warning Kempowski to proceed with caution, "Es scheint an der Zeit, diesen begabten Autor nach dem Ziel seiner Unternehmung zu fragen und inn vor der allzu großen Sicherheit in

33Drewitz 174.

${ }^{34}$ Drewitz 175. 
der Beherrschung seiner eigenen Methode zu warnen." 35 And again with critical reference to the second novel Uns geht's ja noch gold, (in which the narrator is the young Walter), Drewitz affirms:

Die Verniedlichung der Nazi-Zeit und des Krieges durch die Perspektive des Kindes, auch wenn dies nicht in Kempowskis Absicht lag, kam 1971 einem verbreiteten Bedürfnis entgegen, die Vergangenheit zu entschärfen. ${ }^{36}$

In response to such verbal onslaught, Kempowski explains that the three "Sachbücher" are to be included along with the Familienchronik and they provide testimony of his personal awareness of political and historical events. He wishes these books to be recognized as the missing link.

Da ich der politischen Bildung meiner Leser, ihrem Erinnerungsvermögen jedoch mißtraute, veröffentlichte ich 'Satelliten-Bücher,' die der Unkenntnis abhelfen sollten; das Hitlerbuch und das Buch über die Konzentrationslager Haben Sie Hitler gesehen? und Haben Sie davon gewußt?, in denen ich Antworten gesammelt hatte auf die prekärsten Fragen dieses Jahrhunderts. Mit diesen 'Befragungsbüchern' wollte ich die Romane aus dem Allgemeinen heraus katamaranartig abstützen. ${ }^{37}$

35Drewitz 175.

36Drewitz 175.

37Walter Kempowski, “Der historische Teppich," unpublished essay, 1. 
Kempowski believes that the reader should be informed of historical events prior to reading the Familienchronik. This is a major reason why such events remain largely in the background.

5. Kempowski tends to trivialize the Nazi past. The author has been accused, for example, of making light of the plight of the Jews and the political situation during the Nazi regime. This is because these issues rarely seem to be brought forth and labelled accordingly. In light of this criticism, Romanos' comment is befitting of Kempowski: "Instead of assuming the role of social critic and dealing with the social problems of the times, the author turns to the distant past and glorifies it."38 Dietrich Weber explains:

Die bisherige Kritik hat, abgesehen von Hinweisen auf die Tendenz zur Manieriertheit, die bei der durchgängigen Ziselierarbeit allerdings naheliegt, vor allem geltend gemacht, daß Kempowskis Werk durch seinen hohen Anteil an chronistischer Verzeihung von Beiläufigkeiten den Maßstäben, die an eine adäquate Geschichtsschreibung im Roman zu stellen sind, nicht gerecht werde und daß die kritischen Potenzen durch die Art, wie Kempowski seine Kritik vorbringt, Gefahr liefen, nicht aufgenommen und angenommen zu werden. ${ }^{39}$

This "danger" that Kempowski's criticism will not be recognized refers to his seemingly light-hearted mode of exposition. In 1989) 16.

39 Weber 292. 
response, however, Kempowski explains that he saw no point in simply repeating historical facts:

... denn daß es einen ersten und einen zweiten Weltkrieg gegeben hat, 1923 eine Inflation und in den frühen $30 \mathrm{er}$ Jahren eine Wirtschaftskrise, daß 1933 die Nazis an die Macht kamen und daß Millionen von Juden getötet wurden, das alles nochmals aufzutischen, erschien mir überflüssig. 40

In reply to Hage's interview question: "Sie enthalten sich im Tadellöser der Wertung. Ist das nicht gefährlich?" Kempowski replies: "Nein. Ich halte den Leser für intelligent genug, seine Schlüsse selber zu ziehen." ${ }^{n 1}$

It is clear that Kempowski does not wish to write simply an historical account of the war years. Rather, he wishes to portray natural human reactions to circumstances of the political situation during those years. Nonetheless, the theme of National Socialism is omnipresent, thus strengthening the claim for historical validity. B.M. Kane addresses this issue when she writes in reference to two of the Familienchronik novels, Iadellöser \& Wolff and Uns geht's ia noch gold:

Although we are never confronted with any of the pseudo-mysticism of the Nazi self-projection and its manifestations in the rallies, the hysteria and the fanaticism, the deep penetration of National Socialism

40Kempowski, "Teppich" 1.

${ }^{41}$ Hage 343. 
into every aspect of German life is never pushed aside or viewed as an isolated phenomenon which took root inexplicably, without rhyme or reason. Much of the tension and fascination of his work resides in the fact that despite all the affection and good humour which suffuses Kempowski's portrayal of his family and its smug, blinkered values, we can never quite forget that this is exactly the right blend of fertile soil on which Nazism was best liable to prosper and survive. 42

Ingeborg Drewitz, however, does not share this view. She expresses her disapproval of Kempowskis technique, asserting that he all too often represses the issues at hand: "Denn das routinierte Understatement und die allzu sichere Darstellung von Verhaltensmustern reduziert schlieBlich auch die Wahrnehmungsbereitschaft des Lesers . . . ."43 Drewitz is therefore of the opinion that Kempowski's omnipresent "understatement" (pertaining to historical references) diminishes the likelihood that the reader will descry the historical allusions.

Kempowski, naturally, refutes all such claims. And there are critics who willingly support his stance, as well. Brockhaus mentions in his 1971 article concerning the historical validity of Kempowskis' novels that: " . . das Geschriebene [muß] geschichtliche Wahrheit sein." Furthering his statement he asserts:

Kempowskis Bücher sind für uns als Deutschlehrer nicht nur als Literatur von Bedeutung, sondern auch durch den

42Kane 425.

43Drewitz 174. 
direkten Zugang, den sie uns zur deutschen Kultur, dem deutschen Leben, den Sitten und Gebräuchen verschaffen. 44

Kane also responds to the criticism that Kempowski's works are of limited historical value. This critic wrote (following the publishing of Kempowski's third book, Uns gehts ja noch gold) that one feature of the novel is that the events which befall the Kempowski family are not isolated, thus suggesting that they are representative of an entire generation.

It is not however a product of failure of will compounded by changing times, but rather more the result of disastrous historical and social circumstances for which they themselves, as passive and complaisant participants, are in no small measure responsible. The value of these novels is that the fate of the family is neither isolated nor unique. Kempowski succeeds in expanding his own private circumstances into a matrix of attitudes and manners of the bourgeoise at a particularly crucial period in German history and thereby transcends mere autobiographical and family anecdotes and imparts to his work an important political dimension.45

It appears, then, that the views concerning historicity in the Familienchronik are polemic in nature. This study seeks support for those views in favor of "Kempowski as historian."

${ }^{44}$ Brockhaus 51.

45Kane 419. 


\section{CHAPTER II}

\section{THE GERMAN EDUCATIONAL SYSTEM FROM BISMARCK TO HITLER}

Covering the historical period between the beginning of the century to 1963, Kempowski's novels encompass not only a time span of more than half a century, but in addition they extend through four different political regimes. Through the graphic accounts of happenings in the everyday lives of his characters through each respective generation, the reader is offered historical information about each period. Each political regime brought changes to the educational system -- also reflected in the Familienchronik.

Imperial Germany began with unification under Bismarck in 1871. This regime lasted until the Weimar Republic, which began following the end of WWI in 1919. The Weimar Republic endured fourteen years until Hitler came to power in 1933, marking the beginning of the twelve-year reign of the Third Reich. The periods covered in the novels extend from Imperial Germany through the Third Reich. The following is an outline of the individual periods with special focus on their views and philosophies of the role formal education (Erziehung) was to play in their respective societies. 


\section{EDUCATION IN IMPERIAL GERMANY}

As a unified nation, Germany seized control of its educational system for the first time in 1871. Each state had control of its own system, with rules and regulations delegated by various ministeries, according to the size and needs of the individual states. There was no national control of education at this time.46 In the German Empire schools were initially divided into three categories; elementary, middle and secondary schools. Secondary schools were then reserved primarily for priviliged children whose parents could afford to send them to the three-year preparation school (Vorschule), which was the prerequisite for entering the secondary school. Children were required to enter school at the age of six.

Children who came from families of common laborers attended the regular elementary school. Following successful completion of the eight-year elementary school course, most pupils would enter

46Alina M. Lindegren, Germany Revisited: Education in the Federal Republic. (Washington: United States Printing Office, 1957) 1. Here Lindegren provides an outline of the division of such a system with an example from the state of Prussia:

Ministry of Education: elementary, secondary, and higher education; fine arts, religious and medical affairs.

Ministry of Trade and Commerce: vocational schools.

Ministry of Agriculture: agricultural schools.

Ministry of Interior: kindergarten and welfare organizations; organizations for general culture and recreation. 
into an apprenticeship to become craftsmen in a particular trade. Should one desire further education, a three-year evening course was available, following which one would be qualified to attend a middle-technical school. In order to become a master workman in his trade, one had to pass the journeyman examination at these schools.

This school system remained relatively unchanged throughout the remaining years of the nineteenth-century. Innovative trends in German education began first in the early years of the twentieth century. As stated by Robert Frederick Lawson, they included the following: a goal of universal national education -- this was to include all children; the interest of the state was to be extended to the level of dealing with problems of organization and instruction within the school; "conflict between the advocates of authoritarian method and traditional training and educational progressives"47; better training methods for those entering the field of elementary teaching; an expanded program for adult education; "and more realism in instruction in all branches, with better teaching materials.48 Also according to Lawson, certain educational characteristics were incorporated into the curriculum prior to the 1930's. Included in these were "the philosophical orientation toward life and school problems [and[ an authoritarian and nationalistic

${ }^{47}$ Robert Frederick Lawson, Reform of the West German School System. 19451962. Diss. (Ann Arbor: Malloy Lithoprinting, Inc, 1965) 16 
pattern," 49 which were reflected through classroom procedure and instruction. Other characteristics of major relevance included:

Land (state) sovereignty in cultural affairs . . .; a selective system of secondary schooling-- ranging from a terminal elementary school followed by apprentice training to the socially isolated Gymnasium giving a formal, humanistic education--intended on the one hand to prepare the nation's leaders, and on the other, the mass of people. These characteristics were readily connected to Germany's post1933 downfall in later criticism. It was rarely noted during or after the war that an active opposition to rigid instructional forms and controls, and to separate, unconnected, class-connotated school branches had grown during the first three decades of the century. 50

Interesting to note here is that the author of this quote is of the opinion that the German educational system in the pre-Hitler years had only "incidental" effects in bringing about the acceptance of National Socialism.

\section{EDUCATION IN THE WEIMAR REPUBLIC}

Organization of public education under the Weimar Republic was essentially the same as that of the empire, the only major difference being that the Prussian Ministry of Public Welfare was the center for all functions of pubic welfare. In addition, "a

49Lawson 22.

50Lawson 23. 
Department of General Culture was added to the Federal Ministry of Interior for the consideration of educational problems of interest to the Nation as a whole."51 The Weimar Constitution of August 11, 1919 and the Foundation School Law (Grundschulgesetz) of April 28, 1920 moved to make education more democratic than it had been in the Empire. Among the changes was the abolition of the three-year preparatory school. The four-year foundation school (Grundschule) then became mandatory for all children. Each individual state was largely responsible for the regulations of its own schools.

Since the German educational system was (is) rather complex, with its many divisions beginning from the Grundschule and extending through to the Hochschulen, the following example is merely a representation of the system in part. The first eight years of schooling were compulsory, designed to prepare the pupils either for entering the working world or to enter a school of higher learning. The foundation school was to prepare children with a basic training upon which not only the last four years of elementary would be based, but which would also prepare them for the extended instruction of the middle and secondary schools. The task of the foundation school was " to awaken and train the spiritual forces of the children and equip them with a groundwork of knowledge and skills essential for every type of further instruction. ${ }^{52}$ The final

\author{
51 Lindegren 6 \\ 52Lindegren 18-19.
}


four years then, were either to prepare the pupil to enter practical life or to prepare one for further schooling in the academic field.

... instruction was to be based on the self-activity of the pupils, intellectual as well as physical. The pupil's cooperation was not to consist chiefly in the absorption of knowledge; instead the objectives of instruction were to be worked out under the guidance of the teacher through observation, experimentation, investigation, independent reading and verification. .53

The main subjects taught were religion, German, history and civics, geography, natural science, arithmetic, geometry, drawing, music, and physical training. 54

The Weimar period also awakened proposals that were to bring changes to the educational system, many ideas of which arose out of the Reichsschulkonferenz of 1920. Among these changes was the above-mentioned 4-year compulsory Grundschule. The innovative ideas toward school reform in the 1920's became known as the Pädagogische Bewegung or Reformpädagogik. The objectives of this trend were to make education more life-centered, more realistic. Lawson quotes Hyulla and Konetzky, who in 1931, wrote that instruction could be defined as " '. . a an active means of understanding one's personal and cultural environment.' 55

\section{Lindegren 19.}

54The fact that girls were taught sewing and home economics, and that there was manual training for boys is an indication that the educational system was sexist at that time.

${ }^{55}$ Hyulla and Konetsky in Lawson, 18. 
Connecting schoolwork to the present and future situations rather than to past was also advocated.

Although these years generated interest in reforming education, very few ideas were actually put into effect due to the relative shortness of the political regime (from 1919-1933) and unstable conditions. The country was plagued with other problems such as the burden of having to adjust to new political ideologies, rebuilding a government, discontentment between political parties, and devastating economic troubles, to name a few. (Many of the unimplemented "innovative" ideas about educational development from the 1920's were given new life in the 1960's, when many institutions were being reformed.)

\section{EDUCATION UNDER NATIONAL SOCIALISM}

Alterations to the structure of the educational system itself following Hitler's seize of power in 1933 were actually few in number. Those that did occur, however, brought about drastic changes. Under the system in place when the Nazis took over, the national government had had no control over education since the power had been in the hands of the individual states. This was soon changed, however, when one year later on January 10, 1934 (during the Gesetz über dem Neuaufbau des Reiches = the Reorganization of the Nation) control shifted from the state level to the national level. 
From this point on educational concerns were dictated by the national government. In May of 1934 a law established the National Ministry of Science, Education and Public Instruction. This law significantly changed the role of the state ministries, whose new role came to be to perpetrate the wishes/demands of the national government. Funding for the schools, however, still remained in the hands of the states. 56

Under National Socialism there were no changes in the organisation of the eight-year elementary school. All children, regardless of social or economic status, received common schooling

56 The following were the divisions and responsibilities of the National Ministry of Education in place by 1936, as quoted from Lindegren, 7-8:

Central Office:

Administration; legislation; education; relationship with other countries.

Office of the Minister.

Office for Science :

All matters concerning institutions of education and research.

Office of Education:

Elementary and middle schools; secondary schools; vocational; agricultural; and social welfare schools

Office for Folk Culture:

Art academics; libraries; museums and castles; care of public monuments; national parks, etc.; music and cultural art; literature and theater; films and radio.

Office of Physical Education: Gymnastics, physical education, and care of youth.

Land (State) Year Division: Schooling for leaders, inner organisation of the land year. 
during the first four years of the elementary school. A prerequisite for them to be promoted to the subsequent higher levels (i.e. upper four years of elementary, middle, or secondary schools) was the successful completion of these initial years.

With regard to general education between 1933 and the end of WWII, Lawson quotes these years as having been "economically sterile." As stated earlier, few changes were made to the actual structural make-up of the educational system under Nazi rule. The following, however, are the significant ones that were implemented. The first was already mentioned -- the shift of control from the states back to the national government, placing virtually complete control over the future of the youth in the hands of the Nazis. A second major change was the infiltration of Nazi political ideologies throughout the entire educational system.

Important organizational changes by the Nazis included adding the Nationalpolitische Erziehungsanstalt-- a school for political leaders to the secondary school system. There were political organizations for the youth which operated parallel with the schools in order to begin saturating children with political ideologies at an early age. Among such youth organizations was the Hitlerjugend. Understandably the goals of education under the Nazis took on a new meaning. They came to be "education to make radically sound and able efficient individuals; and education to make community members ready for service. ${ }^{57}$

57 Benze, Erziehung im grossdeutschen Reich, as quoted from Lawson, 24. 
Also in conjunction with the educational system was Hitler's plan to create a "pure race." Non-Aryans had to wait until the needs of the Aryans were met before theirs were even considered. German children were indoctrinated to believe they were indeed the superior race.

Under Nazism the child was indoctrinated to hate all outsiders, to engage actively against those 'unclean' or dangerous elements within his country, to distrust people he had heretofore believed in as the closest and most basic to his environment and to fear reprisal for any act or thought expressed however unwittingly, against the fixed life of behavior and belief. 58

Lawson also quotes from an education ministry release from March 27, 1935:

The secondary schools, however, had a more specific responsibility: to educate the physically and morally especially talented part of German youth in such a way, that they are capable of exemplary participation later in elevated or leading positions of our political, cultural, and economic social life. 59

Therefore, in order to be admitted to a secondary school, one was required to be physically strong (no weaknesses or defects) and one was tested mentally not necessarily in terms of how much general knowledge one could demonstrate, but rather how much one was

58Lawson 25.

59 Lawson 24. 
willing to demonstrate one's readiness to adhere to National Socialist standards and ideology.

Support for the extreme emphasis on physical education in accordance with National Socialist ideology finds basis directly in Hitler's Mein Kampf. Lawson cites the following passage from an english translation:

. . The folkish state must not adjust its entire educational work primarily to the innoculation of mere knowledge, but to the breeding of absolutely healthy bodies. The training of mental abilities is only secondary. And here again, first place must be taken by the development of character, especially will-power and determination, combined with the training of joy in responsibility, and only in last place comes scientific schooling. 60

This extreme emphasis on physical education was also closely tied with military training, beginning also in the youth organizations.

As like the rest of the educational system under the Nazis, teachers were not exempt from the infiltration of national socialist ideology. They, too, were forced to conform. For example, in order to retain their positions, they eventually had to prove their loyalty to the party by going through a series of tests. Such tests were devised to expose any weak links in the chain which was to build the nation whose Volk was to be inferior to no other. They had to demonstrate physical as well as military proficiency; they were 
coerced to join a party-affiliated organization; and eventually were required to show proof of Aryan ancestry. 


\section{CHAPTER III}

\section{KEMPOWSKI AS HISTORIAN}

"Mit Hilfe einer Unzahl [ . . . ] Details rekonstruiert Walter Kempowski in seinen Romanen, was in den herkömmlichen Geschichtsbüchern jede Anschaulichkeit verlieren muB: die konkrete historische Situation."61

Problematic in analyzing Kempowski's Familienchronik is that it is often difficult to separate imagination from reality -- they are closely intertwined. The reader is well aware of Kempowski's Zettelarbeit, which serves as the foundation for his writing technique. In the 1972 interview, Hage addresses Kempowski with the question of why he includes the motto "Alles frei erfunden" on the frontis piece of Iadellöser \& Wolff. Kempowski replies," Das ist natürlich ein Witz,"62 explaining that it is only to protect those involved. In response then to the question of whether or not his novels could be loosely termed an autobiography, Kempowski

61 Görtz 251.

62 Hage 340. 
asserts, "Autobiographie ist ja nichts Schlechtes." 63 This remark leads one to believe that the author indeed relies heavily on autobiographical material.

Those who criticize Kempowski for lack of historicity in his texts (founding their argument on the seemingly abundant superficial details) the overabundance of details) may be underrating the value of such references in literature. Through a process similar to that of an historian, many novelists build believable, historically-accurate story based on facts. Kempowski is one such novelist. If used in its proper perspective, literature can serve as a window to the past. One can thus draw a parallel between the creative process of the historian and that of the novelist.

A modern-day historian likens the recording of history to the writing of a literary work:

. . the writing of history is a poetic act, and historical works are a literary form. Historical scholarship is as artistic as it is scientific; it contains creative and fictive elements, it relates both the real and the imagined. It is part memory, part imagination.64

Does this indicate there is no major difference between the writing of history and the writing of a literary work? Both contain many of the same elements. James Smith Allen offers insight into the

63 Hage 340.

${ }^{64}$ Gary D. Stark, "Vom Nutzen und Nachteil der Literatur für die Geschichtswissenschaft: A Historian's View," The German Quarterly 63.1 (1990): 29. 
matter from a novelist's viewpoint, implying that the modern novel, in particular, may prove to be an invaluable source for historical information:

The modern novel, of course, offers descriptions of society. But even more importantly and perhaps more profoundly, fiction shares in the mental world of the ordinary people who read it; an appropriate approach to this source is thus imperative to historians wishing to know more about belief structures in a period.65

To maintain that a work such as the Familienchronik is simply not "historical," then, is to imply that a correlation between the writing of a literary work and the writing of an historical work cannot exist. This question regarding the validity of history vs. literature, however, is age-old. Thus, before one asserts that Kempowski's works are not of historical importance, one must first come to an understanding of the process an historian must go through in order to know history.

65James Smith Allen, "History and the Novel: Mentalité in Modern Popular Fiction," History and Theory 22.3 (1983): 238. 
PARALLELS BETWEEN KEMPOWSKI'S WRITING TECHNIQUE AND THAT OF AN HISTORIAN'S

As has been evidenced, critics are divided when it comes to assessing Kempowski's talent/reputation as a significant author. One reason for the controversy stems from his precarious mode of writing. Without proper insight, one might mistake the author's works as mere Unterhaltungsliteratur. If, however, one carefully parallels Kempowski's method of recording history with that of an historians, one recognizes they have much in common.

Notwithstanding the fact that Kempowski writes "fiction," and that the task of the historian is to record "history," one sees that they employ the same materials upon which to build, construct, and create their stories.

In his article, "Walter Kempowski als Historiker," Franz Josef Görtz delineates the problems that have caused the trustworthiness of the historian to fall into disrepute in recent years. One has had to rethink the concept of history. The initial criticism brought forth by Görtz is that the historian cannot remain objective in reconstructing the past. Görtz cites Jürgen Habermas: "Er [the historian] kann den offenen Horizont der eigenen Lebenspraxis nicht einfach überspringen und den Traditionszusammenhang, durch den seine Subjektivität gebildet ist, nicht schlicht suspendieren." 66

66 Habermas, Jürgen, as quoted in Franz Josef Görtz, "Walter Kempowski als Historiker," Akzente June 3 (1973): 243. 
Görtz explicates further: "Denn über die Bedeutsamkeit eines historischen Ereignisses entscheiden letztlich die Absichten des Historikers, dessen Interpretation feststellbare Wirkungen mit eben diesem Ereignis in ursächliche Zusammenhänge bringt." 67

The second criticism as outlined by Görtz is that the historian tends to organize "history" as an ongoing course of events which are dependent upon one another and which piece the past together harmoniously as if it were a jigsaw puzzle; each part is intricately interwoven with its surrounding parts. Görtz disputes this criticism, however, citing Siegfried Kracauer:

"Eigentlich besteht Geschichte aus Ereignissen, deren Chronologie uns nur wenig über ihre Beziehungen und Bedeutungen mitteilt. Da gleichzeitig Ereignisse öfter wesentlich asynchron sind, ist es in der Tat nicht sinnvoll, sich den geschichtlichen Prozeß als einen homogenen Fluß vorzustellen." 68

Görtz then offers his own definition of history: "Zunächst ist 'Geschichte' nichts weiter als eine trübe Masse von 'Fakten': eine Mischung aus inkonsistenten Elementen, zwischen denen vielfältige Beziehungen denkbar sind."69

Görtz' definition of history could conversely be applied to Kempowski's Familienchronik -- it consists of a collection of

\section{Görtz 244.}

${ }^{68} \mathrm{Kracauer}$, Siegfried, as quoted by Görtz, 244.

${ }^{69}$ Görtz 244. 
"unclear" facts; is a mixture of "inconsistent" elements and is open to a wide range of interpretations.

One thus recognizes the parallels between Kempowski's method of recording history and that of an historian's. Kempowski's works, therefore, like the historians, are constructed from factual materials. The "holes" must be filled with interpretive insights, as well as fantasy in order present a clear and complete picture. In each case it is then the task of the reader to draw his own conclusions.

\section{SOURCES FOR KEMPOWSKI'S WORKS}

As has been indicated from expressions such as "Zettelkasten," "beserkerhafter Sammlerwut,"etc., Kempowski relies heavily on his archive of historical materials which comprise the foundation of his works. To illustrate his dependency on such materials, he explains to Volker Hage that as a boy, one of his favorite pastimes was playing with building blocks. He likens the following boyhood experience with his first serious attempt at writing:

... ich weiß heute noch genau, daß ich mit diesem AnkerSteinbaukasten mal eine Kirche bauen wollte und die Fundamente dieser Kirche, also den Umriß, so groß machte, daß dadurch die ganzen Steine verbraucht waren. ${ }^{.70}$

70 Hage 47. 
He views this incident as "prophetisch beinah," as it presaged a similar experience he had while writing his first book (Im Block) about his struggles as a political prisoner in Bautzen. Just as when he had attempted to construct the make-believe church out of building blocks but had lacked sufficient materials, so it happened when he set out to bring his first book to fruition -- he lacked the necessary resources. Having had exhausted the information he did possess, he was forced to set the project aside until he had completed the much-needed research. It was not until thirteen years later that he was able to complete the book.

Görtz outlines the main sources which have served as the foundation for Kempowski's Familienchronik:

1. mehrere Tonbänder, die eine vollständige Lebensbeschreibung der

M. Kempowski (der Mutter) enthalten;

2. etwa 50 Briefe aus der Zeit 1943-1945 von M. Kempowski, die Einblick in die Zeit -- und Familienverhältnisse gewähren;

3. etwa 50 Briefe aus der Zeit 1945-1948 von M. Kempowski;

4. protokollarische Zeugenaussagen von Zeitgenossen

(Firmenmitinhaber z.B. oder Freunden der Familie);

5. hunderte von Fotos und Skizzen;

6. umfangreiches Tonbandprotokoll des Bruders R. Kempowski;

7. umfangreiches Material, die 'Ahnen' der Familie betreffend.71

71 Görtz 246. 
FAMILIENCHRONIK: HISTORICAL NOVEL OR SOCIAL NOVEL?

\section{Historical Novel}

At this point it is necessary to distinguish between the role history plays in literature in general and its role in a distinct genre: the novel, or more specifically, the historical novel. The Marxist critic, Georg Lukács sheds light on the term historical novel:

Lukács locates the essence of the historical novel in its strong commitment to the portrayal of man's life in history - 'the social and human motives which led men to think, feel and act just as they did in historical reality,' So conceived, the historical novel is not a special genre with rules of its own but a realistic novel having a conscious and fully developed historical awareness. ${ }^{72}$

Unfortunately, however, a simple definition of this particular genre is not as clear as it may seem. "The HISTORICAL NOVEL, like the genus Chrysanthemum, exists in a wide variety of forms, from the weedlike Sweet Savage Love (1974) to the highly cultivated War and Peace (1863-1869)". ${ }^{73}$

Although the historical novel can be broken down into many subdivisions, Romanos distinguishes between two major categories in

72Barbara Kiefer Lewalski, "Historical Scholarship," in Introduction to Scholarship in Modern Lanquages and Literatures. Ed. Joseph Gibaldi, (New York: MLA, 1981) 67.

${ }^{73}$ David Cowart, Histery and the Contemporary Novel. (Carbondale: Southern Illinois Press, 1989) 19. 
accordance with Lukács' above definition. In the first category, "The historical event occupies a central position; it constitutes a point of convergence." In the second, "the historical event is peripheral."74 In the latter, the characters are observers of historical events rather than active participants. Nevertheless, the historical events influence and modify the lives of the characters. These events, however, do not necessarily shape the lives of the characters.

Kempowski's Familienchronik could be classified under one of the subdivisions of the historical novel as described by Romanos -perhaps more precisely under the second category. (The historical frame of reference in the novels, for example, is WWI and WWII.) For the most part, however, these historical references remain in the background and one's attention is focused on the main characters.

It could be said that although deeply-rooted in historicity, Kempowski's novels do not remain true to historical reality. This is because the author seemingly idealizes the historical times and not to depict reality fully. For example, there is an absence of vivid details about the reality of war. That is to say, the author spares the reader details of blood, gore and crimes against humanity. In their stead, the reader experiences the continuity of everyday life. It is from this very standpoint, however, that Kempowski believes he is making his strongest statement in criticizing the past. 


\section{Social Novel}

Perhaps even more befitting of the Kempowski Familienchronik would be to maintain that it should be of vital interest to the social historian. Recent social history does not concern itself with what a few intellectual thinkers of the day thought. Rather, it concentrates on the mundane.

Social historians are interested not in what a few creative people thought but in how most people actually lived -- and in most historical situations, the lives of everyday people are largely untouched by the intellectual currents that come to expression in imaginative literature. Literature is of use to the social historian only if it provides factual information or useful knowledge (evidence) about the past social life of ordinary people..$^{75}$ (italics added)

This is precisely what Kempowski does and as he indicated in a recent interview, one should not view history from a theoretical standpoint -- one should focus one's attention on factual sources:

". . Geschichtsbetrachtung darf man niemals von der Theorie her aufziehen, sondern immer von den Quellen, den Fakten, Tagebüchern, Zeitaussagen, das heißt, Geschichte muß von unten aufgearbeitet werden."76 Kempowski agrees with the social historian that history should be done from "below."

\section{Stark 22.}

${ }^{76}$ Alfried Nehring, "Endlich mit der Marienkirche ....," (Interview with Walter Kempowski -- exact date unknown but I estimate early 1990) 6

Walter Kempowski was interviewed by East German film-maker Alfried Nehring, who plans to turn the novel Aus Großer Zeit into a movie for television. 
The author portrays his characters in the novel Tadellöser \& Wolff, for example, as seemingly care-free, light-hearted individuals despite the horrors and atrocities of war that surround them. Through this approach author believes to be depicting the "ultimate evil," namely, that no matter what the circumstances, everyday life must continue as well as possible. The "evil," then, is that in order to function in everyday life, one must resign onesself from the "outside world," thereby choosing not to accept responsibility for events which occurr. It is this portrayal of the fact that everyday life does continue that draws negative attention from Kempowski's critics. They feel that since he does not depict history truly as they believe it to have transpired; that he is making light of the situation and ignoring his social responsibilities.

Kempowski, however, wants to depict that portion of history that is never learned in school. He wants to expose the family life that took place and to show that the everyday occurances of the middle-class life continued. As the author expressed in the interview with Alfried Nehring:

daß da auch Familienleben stattfand, der bürgerliche Alltag weiterging, war ihnen von ihren Lehrern nicht berichtet worden. Die Tatsache, daß weiter getanzt wurde, gelebt und geheiratet, Kinder gezeugt wurden, macht ja die Nazizeit sehr viel schlimmer. Die Gleichzeitigkeit von Konzentrationslagern und Cafehäusern ist für mich auch unerträglich. 77

77 Nehring 7. 
Herein lies the danger, believes Kempowski. It is because people were willing to choose ignorance (so as not to be held accountable for what the "Nazis" did) that history could repeat itself. A fitting example is cited by Nehring, who recalls that in Tadellöser \& Wolff, the mother of the protagonist comments as Russian soldiers are marching in to occupy the city of Rostock, "Eigentlich sind wir ja auch die Sieger, wir waren ja keine Nazis."78 As Kempowski tries to portray, "normal citizens" never realize the part they play in allowing such happenings to take place.

One cannot deny the presence of such indispensable cultural insights, which are an inherent characteristic of the Familienchronik.

\section{PROBLEMS AND PITFALLS OF APPROACHING A NOVEL THROUGH THE PERSPECTIVE OF A SOCIAL HISTORIAN}

In the previously mentioned article, Stark delineates the areas of concern of the social historian in using literature as an historical reference. Let us consider these in relation to the Kempowski novels.

1. No matter how detailed, literature does not simply supply historians with a window to the past. This point deals with "intentional fallacy" and stresses that "intention is not the same as achievement." As stated previously, Kempowski makes his intention 
clearly known so the question is whether or not the author's intention is discernible as such to the reader.

2. Rule of immediacy -- The historian must ask, how far removed is the text from the actual occurence. Obviously the ideal and most accurate source for the historian would be the authentic documents written by those who witnessed an event first-hand. Fans and critics of Kempowski know that his career/talent as an author is based on an inexhaustible resource of such materials -- his "Zettelkasten" -- the archive of letters, eye-witness accounts, pictures, photos, diaries, interviews, etc. of the historic times in his novels. Arranged chronologically, these information cards comprise the major source of information on which each of the novels of the Familienchronik is based. For this method the author has been both praised and criticized -- praised for his ability to recall minute detail but criticized for leaning too heavily on historical information and not enough on the creative energy expected of a major novelist.

3. Socially realistic literary works may contain many social details but do not necessarily reflect historical conditions accurately. This is naturally a concern for the Kempowski critic but poses no major problem, for as Stark later asserts:

We are more likely to encounter historically accurate (and independently confirmable) information from an author's detailed descriptions of everyday physical objects or the material environment than from his/her 
treatment of socially interesting -- but more complex and abstract -- 'facts.'79

The Kempowski's specialty is just that -- describing everyday physical objects or the material environment in minute detail. The author's talent in this respect could be partially accredited to his "style" of writing, i.e., much of the detail of the physical environment comes from photographs. Another reason for his ability to recall details stems from the eight years he spent as a political prisoner. There he had ample time to practice what is referred to as "Gedächnistraining --" 80 or thought-training. During these years of confinement Kempowski helped to pass the time by doing recall exercises. He would ask himself, for example, "What did I do on such and such a day in the year. . . ?" This so-called "training" resulted in the author's ability to reconstruct the past with vivid description. As the title of Gunther Alf's study can attest to, Kempowski readers who delight in having their own past reconstructed for them agree that, yes, "Genauso war es . . .."81

At this point Kempowski critics would seem to have very little support. Stark warns, however, that one must be careful not to infer that

${ }^{79}$ All quotations form this section are from Stark 22-24.

${ }^{80}$ see interview with Volker Hage, "Eine Art Gedăchnistraining."

${ }^{81}$ Gunther Alfs, "Genause war es...," (Oldenburg: Heinz Holzberg Verlag, $1982)$. 
. . because an author accurately depicts certain incidental elements of the physical environment of the past, he/she also gives an accurate account of the larger social events, situations, or relationships with which those physical descriptions are associated in the work. 82

One must thus proceed with caution.

4. Historians who comb literary works for useful historical details too often forget that in a literary text, details are used for aesthetic purposes. There is the danger that when literary texts are extracted from their "aesthetic content" that they will be misinterpreted. One should pay particularly close attention to the word "aesthetic," for this is the main concern of the novelist. No matter how true to history his source material is, the novelist has the freedom (and power) to delete, add, manipulate, emphasize, etc. -- all for aesthetic purposes. As Stark explains, a novelist is responsible to form in a way that the historian or sociologist is not. With this in mind, the job of the critic becomes even more specific. With Kempowski, however, this issue is not so crucial, for he in no way tries to conceal the sources which provide the backbone for his novels. Should one question the validity of the historical references, answers could be sought, if not in history books, then in the Kempowski archives. 


\section{CHAPTER IV}

\section{ERZIEHUNG AND HISTORICITY IN THREE NOVELS OF THE}

\section{FAMILIENCHRONIK}

Kempowski touches on the topic of formal schooling in each of the six novels of the Familienchronik -- although some passages are more in depth than others. In each instance his scrupulous manner of portrayal elucidates the educational systems and philosophies of Germany's past in a way that history books do not. The reader becomes cognizant of the responsibilities of the school system not only from the standpoint of the state but from the standpoint of the people, as well. The following are examples from three novels of the Familienchronik which graphically display Kempowski's ability to portray historical times through the example of Erziehung spanning the period 1900-1945.

The author reflects the changes (and/or ways of thinking) that occured in the educational processes throughout the various political regimes. It is through these portraits of the educational scene that Kempowski attempts to answer the previously-stated question which he formulates in the article, "Über die Allgegenwart von Erziehung": "Wie wurden sie auf den Weg gebracht, die Menschen, 
die das Dritte Reich verursachten ...." "83 In the following examples, this "Weg" discusses what role the educational systems played in influencing the German people's way of thinking that allowed Hitler to come to power and then proceed to drastically alter their lives. Unlike Lawson, who believes education only played an incidental role in allowing the Nazis to come to power (see Chapter II), Kempowski is of the opinion that education was a major factor in instilling certain belief systems.

\section{AUS GROBER ZEIT (1900-1918)}

Reaching back to the Kaiserzeit and extending through the postWWII period, Kempowski introduces the origins of the family that emerges in the later novels of the series. As Kempowski explains to Volker Hage, one of the reasons for writing about the Kaiserzeit was “. . . [um] die Erziehung der Eltern bloßzulegen und der Frage nachzugehen, nach welchem Gesetz diese Generation angetreten ist, die ja dann die Nazizeit verschuldet hat."84

Aus großer Zeit (1978) begins with the description of three pictures of Rostock, each telling its own history of the city. Kempowski, having established the setting, introduces the people.

83Kempowski, "Erziehung" 1.

84Volker Hage, "Der Erfolg ist ein Glücksfall" (Interview, August 1981) in Die Wiederkehr des Erzahhlers: Neue deutsche Literatur der siebzioer Jahre. (Frankfurt/M: Verlag Ullstein GmbH, 1982) 187. 
"Die Leute, die in Rostock wohnen, Fabrikbesitzer, Handwerker oder Arbeiter, heißen immer noch Kröger, Kramer oder Kröpelin. Seit kurzem heißen sie sogar Kempowski... . 85 The scene is thus established.

This novel is chronologically the first volume of the Familienchronik, although it was not the first written. It was one of the most popular, most widely-read novels of the series. Karl Kempowski, whose fictive role represents the author's father, is the central figure. He is introduced as a boy.

Hier wird faktisch die Entwicklungspsychologie eines jungen Mannes dargestellt, der sich dann in der Republik als, 'konservativ bis auf die Knochen' (Tadellöser 231) verstehen muß. Hier liegt auch eine mögliche Didaktik, die dieser Chronikabschnitt -- wie auch die ihm folgenden -- zwar nicht ausführt, aber doch anbietet: erkennen zu lassen, daß gesellschaftpolitisches Handeln seine 'vorpolitischen' Wurzeln im Lebenslauf hat -- eine Erkenntnis, die zwar auf der Hand liegen sollte, sich aber gerade für entferntere Geschichtsabschnitte oft nicht einstellen will. 86

One thus gets acquainted with Karl's generation and is offered insight as to how the characters were shaped by societal values and ideals. One not only meets Karl, his sister and parents, but the family which eventually becomes Karl's in-laws as well -- the de 1978) 17.

85Walter Kempowski, Aus aroßer Zeit. (Hamburg: Albrecht Knaus Verlag,

${ }^{86}$ Manfred Dierks, Walter Kempowski. (München: Verlag C.H. Beck, 1984) 70. 
Bonsacs, whose four children include Margarethe (Karl's future wife).

The reader follows the protagonist, Karl, through his adolescent years -- to the point where at fifteen, he meets Margarethe de Bonsac and falls in love; at sixteen, so full of patriotism and the desire to serve his country, he voluntarily enlists in the army despite his age. He quickly works his way up in rank to lieutenant. His experiences include an awakening to the realities of war and witnessing the tragic death of his boyhood friend. At the end of the story, exhausted and defeated, the remaining soldiers march home, Karl among them. Kempowski ends the novel with a hint of the futility of war: ". . . Nicht, daß sie tot sind, all die Kameraden, ist der Schmerz, sondern, daß man sie vergessen wird. Trotz aller Monumente. ${ }^{87}$

For the first time in the writing of the Familienchronik, Kempowski can no longer draw on personal experiences, for he writes of times which preceded his birth. He must therefore rely heavily on his acquired experiences, namely, imagination, historical accounts of this period, and testimonies of friends and relatives who were Mitlebende dieser Jahre. For the first time, despite the hundreds of biographies available for background information, Kempowski has to create. This naturally raises the question, can an author accurately depict a historical period which he has not

${ }^{87}$ Kempowski, Zeit 448. 
personally experienced? Kempowski addresses this issue: "Als ich daran ging, ein Buch über die Kaiserzeit zu schreiben, hieß es: Das wird er nicht können, denn er hat die Zeit nicht miterlebt. Als ob ein Author je an die eigene Epoche gebunden wäre."88

The author explains that simply because one has lived through an experience, this does not automatically ensure that one was conscious of the events that were occurring. "Augenzeuge ist man nicht automatisch. Vieles, was sich ereignete zu unsern Lebzeiten, fällt nicht in unsere Sinne." ${ }^{n 9} \mathrm{He}$ further points out that events which precede one's birth can become a part of one's own experiences as well, for there exist what he terms "Erzählbrücken." These, he explains, are what are passed down from one's parents. "Zur Erlebnisgrundlage eines Menschen gehört immer auch das, was inm von eigenen Eltern überliefert wurde."90 Kempowski's remark gives the impression that "second-hand" information, therefore, almost raises one to the ranks of an eye-witness. The author's remarks, however, should not be taken too seriously out of context. (One must not forget the massive source materials which the author employed as the foundation for the novels). However, the fact that Kempowski writes of times which precede his birth should not automatically discount what he attempts to portray historically.

88Walter Kempowski, "Mangelndes Verstăndnis," unpublished essay: 1. 89Kempowski, "Verstăndnis" 1.

90Kempowski, "Verstăndnis" 1. 
Such statements by the author cannot be used as direct "proof" of the novels' contents. But they can serve as guidelines from which to judge the texts. Besides, it is not necessary for one to rely on the author's account to interpret the Familienchronik -- the texts speak for themselves.

Kempowski is of the opinion that it is the task of the novelist to recognize that his readers will be comprised of one of the two categories -- those who were eyewitnesses to historical events and those who were not. It is thus imperative that the "facts" be presented accurately, that they may be easily recognized by both types of reader.

Aus großer Zeit is stylistically unique. Point of view changes in the novel. There is no single "ich" narrator throughout the entire story. Rather, it is told by continually-changing narrators, each new person relating events from his/her own perspective.

Dieses heiter-pittoreske Familienepos beginnt mit dem Band Aus großer Zeit, in dem der Chronist und ein Reigen aufgerufener Augenzeugen vom Ahnherrn Robert William Kempowski, dessen Frau Anna sowie ihren Kindern Karl und Silvia berichten, von Kaiser Wilhelms Zeit, dem Ersten Weltkrieg und dessen Ende im Jahr 1918.91

Also stylistically interesting to note is that the story is told in the present tense, which Kempowski explains, has a specific purpose:

91Kurt Rothmann, "Walter Kempowski," in Deutschsprachige Schriftsteller seit 1945 (Stuttgart: Philipp Reclam jun., 1985) 209. 
Dadurch, daß ich im Präsens schreibe, war das alles viel einfacher. Es ist so, als ob ich hinter den jeweiligen Figuren stehe und an ihrem Kopf vorbeigucke -- wie sehen die das jetzt? Ich nenne es ein 'historisches Präsens,' weil man eigenartigerweise mit dem Präsens der Vergangenheit besser beikommt. Ich glaube, wenn man im Imperfekt schriebe, dann müßte man begründen, warum man das eigentlich kann. Durch die Verwendung des Präsens wird die Begründung überflüssig.92

Karl Kempowski's initial educational experiences are from Fräulein Seegen in her private school. The narrator begins with the facts: "Bei Fräulein Seegen lernt Karl Schreiben und Lesen und vor allem natürlich Rechnen ...."93 and follows with elaborate details so characteristic of Kempowski's writing style:

Zur Schiefertafel, die in einem Holzrahmen gefaßt ist und auf der einen Seite Karos und auf der andern Seite Linien hat -- sie knackt leicht kaputt -- gehört eine lackierte Schwammdose aus gepreßter schwarzer Pappe mit einem Blumenbild obendrauf. Und die Griffel, die mit silbern gemusterten Papierumhüllungen versehen sind, liegen im doppelstöckigen, ebenfalls mit Blumenbild versehenem Griffelkasten. 94

92 Hage, "Glücksfall" 189.

93Kempowski, Zeit 36.

94Kempowski, Zeit 36. 
The punctiliously-offered particularities, such as the above example provides, add flavor, as well as equip the reader with a Zeitgefühl. One not only learns what the pupils were taught and how, one sees the materials they had to work with.

Kempowski continues, explicating the curriculum in yet more detail: "Schreiben, Rechnen, Lesen. Und natürlich Religion. 'Was tat Jesus, als er zwölf Jahre alt war?'"ngs One sees the rigidity of this learning environment.

In Religion darf man nicht lachen, das wissen sogar die Abc-Schützen, auch wenn das Lachen der Katze gilt, die draußen aufs Fensterbrett gesprungen ist und mit dem Pfötchen an die Scheibe rührt, in Religion muß man ernst sein. 96

Also included in the curriculum is music. "Wenn mal 'Singen' ist, müssen die Kinder auf den Tischen sitzen, die Beine auf der Bank."97 One detects, however, that it does not belong to the basic courses, as indicated by the word mal. According to Magdalene Weibels, this is due to the fact that educational reform 98 had not yet begun in

95Kempowski, Zeit 36.

96Kempowski, Zeit 36.

97Kempowski, Zeit 37.

98The Pedagogical Reform Movement (Reformpädagogik) swept through Europe and North America between the years 1890-1930. It occurred in two phases. The first phase occurred approximately 1890-1920 but as stated above, did not reach Germany until after 1910. The main objectives of this first phase were to fundamentally revise traditional pedagogy. Strength for the movement came largely from individual reformers who were devoted to furthering their cause. As the Kempowski text indicates, 
Germany during Karl's elementary grade years (approximately pre1910).99 Music was not made part of the official curriculum until 1921, when the Prussian Guidelines were established, ensuring the opportunity for pupils to develop their musical talents.100 As Weibels explains, songs were chosen according to pedagogical principles. 'Der 'liederliche Augustin' wird dem 'guten wohlhabenden Müller' gegenübergestellt."101 Through such song texts the children learned that "Geld zu haben ist gleichbedeutend mit 'gut,' sein Geld zu verschwenden ist 'unverständlich.'"102

In this Kempowski novel discipline is strictly enforced and obedience is instilled in the pupils. Reprimands await even those, for example, who speak too softly: "Wer zu leise spricht, muß sich unter diese Linde stellen und von dort aus vorlesen oder sein Gedicht aufsagen . . . ."103 That is to say, the pupil outside the school must recite loudly enough for those inside to hear! Another example of disciplinary measures for misconduct: he who becomes frech or

music was not considered to play a vital role in child development prior to this reform movement. It was therefore not an official part of the curriculum.

${ }^{99}$ Magdalene Weibels, "Die Darstellung von Erziehung und Schule in ausgewahlten Werken Walter Kempowskis," Schriftliche Hausarbeit, written under the direction of Professor V. Neuhaus, (KöIn: Institut für Deutsche Sprache und Literatur, 1989): 27.

${ }^{100}$ H.J. Schmidt, as quoted in Weibels, 27.

101 Weibels 28.

102 Weibels 28.

${ }^{103}$ Kempowski, Zeit 36. 
rambunctious must stand beside a cabinet in the hallway: "Der muß hier neben dem Schrank stehen und warten, bis er wieder hineindarf und an dem Unterricht über Windmühlen . . . teilnehmen."104

Exactness in performance as well as in conduct is demanded of the children. Magdalene Weibels ${ }^{105}$ cites the following example of teacher expectations in the pupils' writing and arithmetic performances: Concerning writing; "Wenn die ' $i$ ' in einer Reihe stehen, ganz exact, und auch kein einziger Tüttel auch nur einen halben Millimeter größer ist als der andere . . . ."106 Pertaining to arithmetic: "und wenn die Rechenkästen genau ausgezählt sind und unten und oben ein Rand freigelassen ist (ob die Aufgaben stimmen, ist weniger wichtig), dann gibt es solche Briefmarken."107 Exactness is thus stressed and achievement is rewarded. Rewards are materialistic. The pupils receive stamps. Recipients are beckoned to approach the teacher's desk in order to be recognized in front of their peers. Although the protagonist, Karl, finds the stamps intriguing and he does indeed receive some, they are not enough incentive to ward off trouble in reading.

Karl's transition from elementary school to high school does not go without emotion. "Von Fräulein Seegen ist er unter Tränen

\footnotetext{
${ }^{104}$ Kempowski, Zeit 35.

105 Weibels 27.

106Kempowski, Zeit 38.

107Kempowski, Zeit 38.
} 
entlassen worden."108 The narrator introduces Karl's high school experiences by offering a description of Karl in his class picture (typical of Kempowski's writing style): "Aus Karls Pennälerzeit hat sich ein braunes Klassenphoto erhalten: fünfundzwanzig Jungen mit Schülermützen harmonisch aufgestellt, einander brüderlich die Hände reichend. Vorn rechts steht 'Körling', . . . ."109

The daily structure is outlined: "Vormittags vier Stunden, nachmittags drei."110 The reader also receives further insight into the regimental structure of the school system when, in chapter twelve, a former classmate of Karl's recollects:

Das Schulsystem hatte natürlich auch seine guten Seiten. Das Wichstigste war vielleicht die unumstößliche Ordnung. Der Stundenplan galt für das ganze Jahr, da mochte kommen, was wollte. Ich kann mich nicht erinnern, daß der Stundenplan je geändert worden wäre. Schon die äußerst seltene Erkrankung eines Lehrers galt als größte Überraschung, und selbstverständlich wurde er dann auch vertreten. Der Unterrichtsausfall war gleich Null, und das bei sechs bis sieben Stunden pro Tag!111

${ }^{108}$ Kempowski, Zeit 73.

${ }^{109}$ Kempowski, Zeit 73.

110 Kempowski, Zeit 73.

111 Kempowski, Zeit 124. 
Instruction techniques consist largely of memorization. Weibels makes reference to the "Eintönigkeit" and "Langeweile"112 of this type of instruction as evidenced by the narrator's remarks: "Träge schleichen die Stunden hin. Murmelnd und leiernd wird repetiert"113 (italics added). Examples of such repetition drills are then offered: "Geschichtszahlen müssen auswendig gelernt werden, vorwärts und sonderbarerweise auch rückwärts."114 Other such examples of memorization techniques follow: "'Iller, Lech, Isar, Inn, fließen zu der Donau hin . . . !'m115

Discipline, once again, is strongly enforced. As Weibels explains, " . . . die Schüler sollen zum Gehorsam erzogen werden." 116 The teacher, Peule Wolff, makes his authority clear -- he will tolerate no back-talk from his students:

'Kempowski sitzt eine Stunde nach.'

' . . a aber Herr Doktor!'

'Kempowski sitzt zwei Stunden nach!'

' . . a aber Herr Doktor!'

'Kempowski sitzt drei Stunden nach!'117

112 Weibels 28.

113Kempowski, Zeit 75.

114Kempowski, Zeit 73.

115Kempowski, Zeit 73.

116 Weibels 28.

117Kempowski, Zeit 75. 
Another example of the teacher's absolute authority is that he has the right to discipline by corporal punishment. The Hausmeister observes the following scene from the vantage point of a peephole: "Manchmal linst der Hausmeister durch das Loch, wenn's grade mal 'hau-hau' gibt, wenn sich ein Junge das Hinterteil reibt. 'Jija-jija', sagt Peule Wolff und wischt den Stock ab, als ob der dabei dreckig geworden wäre."118 It is through the employment of such extreme disciplinary measures that the teacher gains respect. 119

This respect seems to have worked wonders even in the case of the most difficult students. Karl, characterized by a former classmate as "frech und faul,"120 seems to radically alter his behavior following a disciplinary encounter with Oberlehrer Lehmann: "Über die erste wahnsinnige Ohrfeige, die Karl da kriegt [from Lehmann], ist Karl sein ganzes Leben lang verdutzt. 'Von da ab ging's', heißt es."121 Lehmann, therefore, has won Karl's respect.

Karl has further encounters with Oberlehrer Lehmann when he is sent to him for tutoring in Latin. Karl's experience with family friend Ludwig Ahlers as his tutor has not brought about the desired results. Ahlers employs his own memorization tactics, exemplifying how one should not learn. He explains to Karl: ''Cu fortis stalleris',

118 Kempowski, Zeit 75.

119 Weibels 28.

120Kempowski, Zeit 125.

121 Kempowski, Zeit 77. 
sagt er zum zehnten Mal und liefert die Erklärung gleich mit: 'Kuh fort ist, Stall leer ist"..122 Lehmann, however, whose task it is to re -teach Karl, cannot endure such abominations of the Latin language: "Oberlehrer Lehmann hält sich nicht damit auf, daß 'tre lamentius' 'drei lahme Enten' bedeutet, was der alte Ahlers für bildungs-notwendig hielt, oder 'rebaum declatrus' 'das Reh klettert den Baum hoch!'"123 During such tutoring sessions with Lehmann, Karl must sit up straight, his hands on his knees. One sees that he is making progress, not only in that his Latin is improving, but his attitude toward learning is augmented as well: " . . . er kann gar nicht genug davon kriegen."124 Karl has therefore learned not only to respect authority, but also that it can bring personal rewards.

The term Lebensraum appears early in the novel, thus justifying the fact that the term did not begin with Hitler. Following one of Karl's tutoring sessions at the home of Lehmann, Karl receives a lesson in German history: “. . . er [Lehmann] erzählt Karl vom Auf und $A b$ des Reiches: Immer wenn eben alles in Ordnung ist, dann kommt der Papst oder der Franzose . . . Oder ein schwacher Fürst vermasselt alles."125 He tells of Bismarck and Napoleon; unfolds maps and locates battle sights. Finally, he shows Karl his collection

\footnotetext{
122Kempowski, Zeit 76.

${ }^{123}$ Kempowski, Zeit 77 .

${ }^{124}$ Kempowski, Zeit 78.

125Kempowski, Zeit 78.
} 
of Berliner Illustrirten. Karl then, at this point in reverential fear of his teacher, voluntarily learns the names of Germany's cruisers and battleships: . . . und ganz freiwillig lernt Karl die Namen dieser Schiffe auswendig, und bald kann er sie gerade so gut daherrappeln wie die unregelmäßigen Verben."126 Oberlehrer Lehmann then proceeds: "Deutschland braucht Lebensraum, mein Jung . . . und Lebensraum gibt's nur im Osten."127 He then continues, telling Karl how he would handle the emigration procedures if it were his responsibility. Lehmann concludes this session by giving Karl books by Paul de Lagarde. " . . . da steht das alles noch viel besser drin, als er ihm das erklären kann."128 This experience no doubt leaves a lasting impression on Karl. His sudden change of behavior as well as his new-found eagerness to learn are indication alone that he holds his teacher in highest regard. Karl wishes to please him. One can also be assured that the concept of Lebensraum has left Karl with new ideas to speculate -- even when at this point, perhaps only in his subconscious.

In chapter thirty-six Kempowski once again gives the reader an inside look at the German educational system during the Imperial Regime -- this time through the perspective of a girlfriend of Grethe's. In this chapter, entitled, "Die Freundin," the narrator tells

126Kempowski, Zeit 79.

127Kempowski, Zeit 79.

${ }^{128}$ Kempowsk, Zeit 80. 
of her common experiences with Grethe as the two entered training in 1915 to prepare them to become Kindergarten teachers. Dierks comments: "Über . . . Ausbildung wird berichtet -- und da das immer wieder einmal unter alternativen Namen modern ist, soll dies Ausbildungsprogramm der sich nachhaltig selbst reformierenden bürgerlichen Pädagodik hier zitiert werden."129 Part of their training included learning "Falten, Stricken und Kleben"130 in order to have a means to keep the children occupied. The academic part of their training then included such subjects as "Psychologie, Bürgerkunde, Pädagogik und Gesundheitslehre . . . ."131 Educational ideology was also an integral part of their studies: "Pestalozzi lasen wir, Rousseau, Kerschensteiner und natürlich auch 'Das Jahrhundert des Kindes' von Ellen Key. ${ }^{132}$

Eighteen months of course work were followed by a period of practice teaching for which both Grethe and her friend (the narrator of this chapter) were assigned to undergo at the same school. It was

129 Dierks 65.

130Kempowski, Zeit 339.

131 Kempowski, Zeit 339.

132Kempowski, Zeit 341 . The narrator of this passage and Grethe were obviously products of the second phase of the Pedagogical Reform Movement (19201930), as is evidenced by their teacher-training education as well as by the teaching ideologies/methodologies, which they themselves employ as teachers. The abovementioned names, i.e. Kerschensteiner, Pestalozzi, Ellen Key -- were among the important representatives of the movement. Included among their most important educational objectives were individuality, spontaneity, the importance of activity and aiding the pupils in how to be democratic. Other changes arising out of this phase of the movement included the Jugendbewegung, group activities, learning by "experience," etc. 
located in a district where the "poorest of poor" lived and where the majority of the children had to be picked up at home because their mothers worked in the Munitionsfabriken and had no time to care for them. The two practicum teachers considered this part of their Kriegsdienst 133 as women. They earned a mere one hundred twentyfive Marks per month because ". . d die sozialen Stellen wurden ja furchtbar schlecht bezahlt." ${ }^{134}$ The teacher training program at this school is further explicated by Dierks:

-- Es sind dies zwei sozialtypische Entwicklungsbahnen, die auf die dann mögliche Weise auch in der Zeit der Republik von den beiden [the narrator and Grethe] fortgesetzt werden. Ihr Beginn bedingt ihren Fortgang. Einiges am 'typisch bürgerlichen Verhalten' der Kempowskis während der Republik und unter dem Faschismus wird von hier aus als logische Verlaufsform aus solchen Anfängen erklärbar und -- potentiell -- auch zu verstehen sein. ${ }^{135}$

Formal education, then, as Dierks supports, was an instrumental factor in conditioning the German peoples' way of thinking. It was manifested in all facets of their lives. Ideologies which were passed on from institution to teacher to pupil thus penetrated their way into the whole of society. Kempowski demonstrates this phenomenon through the example of Karl's elementary- and

${ }^{133}$ Dierks 66.

${ }^{134}$ Kempowski, Zeit 341.

135 Dierks 66. 
secondary school experiences; through the teachers who serve as role models for pedagogical principles of the day; and through the various narrators' recounts of their educational experiences.

\section{SCHÖNE AUSSICHT (1919-1938)}

The third novel of the series, Schöne Aussicht (1981), fills the chronological gap between Tadellöser \& Wolff and Aus großer Zeit. It was this novel that Kempowski enjoyed writing the most. "Ich habe an diesem Buch wahnsinnig gern gearbeitet."136 The author reveals a little about the structure: “ . . . die Kapitel sind sehr lang -- wohl keines unter 35 Seiten."137 Also unique to this novel is that there is only one narrator. Another special feature is that there exists a "theoretical theme" for the first time in a Kempowski novel, namely, that of Erziehung . Kempowski explicates:

Erst beim Schreiben merkte ich, daß praktisch jedes Kapitel nicht nur von der Erziehung des Kindes Walter und seiner Geschwister handelt, sondern daß im Grunde jedes Kapitel sich mit Erziehung überhaupt befaßt. [ . . .] In jedem Kapitel taucht eigentlich die Frage auf: Inwiefern werden die Personen, die hier vorkommen, von ihrer Umwelt oder voneinander erzogen? ${ }^{138}$

136 Hage, "Glücksfall" 190.

137Hage, "Glücksfall", 190.

138 Hage, "Glücksfall" 190. 
Erziehung, in this context, connotes the general definition of the term, but certain sections of the novel are dedicated solely to exposing the school system -- chapter twelve being the most exemplary. In this chapter Kempowski delineates "zehn Stunden"139 which above all depict his "Vorliebe für Erlebnispädagogik."140

Since this novel is the sequel to Aus großer Zeit, the reader is now acquainted with the Kempowski family. The setting is between the world wars -- approximately 1923-1939. As the story opens, the newly-weds, Karl and Margarethe, begin an adjustment period in their lives. Despite an unstable economy, they plan to start a family. "[Schöne Aussicht handelt davon,] . . . daß zwei junge Menschen, Karl und Grethe also, sich alles so schön ausmalen, wie wunderbar das nun werden wird mit der jungen Ehe, mit Kindern."141 The situation, however, seems to be out of their control. In the midtwenties inflation has risen to astronomical figures and nationalism/Nazism is on the rise:

"Und es kommt ein Kladderadatsch nach dem anderen. Es bleibt nicht bei Inflation, Weltwirtschaftskrise und Machtübernahme, sondern es kommt dann auch zu den bekannten Ereignissen, die schon, wenn man das diesmal aus dem Blickwinkel der Eltern schreibt, ihre Schatten über sein junges Leben werfen können. ${ }^{142}$

139Hage, "Glücksfall" 190.

140Hage, "Glücksfall" 190.

141 Hage, "Glücksfall" 188.

142Hage, "Glücksfall" 188-9. 
Karl and Grethe are naturally concerned about their children's upbringing, as well as their formal education. Each stemming from a different family background, it is unavoidable that each bring his/her own child-raising philosophies into the marriage. This becomes apparent in the disciplining of their children -- Ulla, the eldest, Robert and eventually der kleine Herr Kempowski, Walter. Weibels cites the example of when Robert receives a beating from his father for having run away from his mother. ${ }^{143}$ Karl's philosophy is: "Wer nicht hören will, muß fühlen." 144 Grethe, on the other hand, is convinced: "Mit Liebe geht das auch."145 She feels that Karl has no notion of how children should be raised. ${ }^{146}$ She believes that her training as a kindergarten teacher has qualified her much more readily than her husband, who has had no such formal training. This indicates to the reader just how deeply-rooted Grethe's teachertraining has become. She not only wishes to apply her learned philosophies in the classroom but in her own home, as well. "Um zu beweisen, daß ihre Erziehungsmethoden mehr Erfolg haben als Karls, versucht Grethe, bei ihren Kindern das anzuwenden, was sie während ihrer Ausbildung zur Kindergärtnerin gelernt hat."147 As stated, she

${ }^{143}$ Weibels 32.

144Kempowski, Aussicht 158.

145Kempowski, Aussicht 163.

${ }^{146}$ Kempowski, Aussicht 118.

147 Weibels 33. 
believes in correcting a child with love. "Dazu gehört vor allem, daß sie den Kindern mit Liebe, Zärtlichkeit und Verständnis entgegenkommen will und unnachgiebige Strenge rigoros ablehnt."148 This is an example of instructional ideologies that were supported by the Reformpädagogik.

According to Dierks, Grethe is the right person for the job of raising the Kempowski children according to standards set by society. Her child-raising philosophies correspond with those of their social class: "Die Aufmerksamkeit, die auf sein [Walter] und seiner Geschwister fortkommen verwendet wird, gilt zugleich der Institution Erziehung in ihrer bürgerlichen Ausprägung." ${ }^{149}$ Grethe recognizes that the responsibility of educating her children in the proper manner must begin at home.

. . . dafür haben sich seit der letzten Schulreform diese beiden Fachwörter eingebürgert, in die 'primäre' und 'secondäre' 'Sozialisation', also die des Kindes bis zur Schulreife und die, die dann der Schule und weiteren Bildungseinrichtungen überantwortet ist." 150

Dierks further explicates the role of education for the betterment of society:

148 Weibels 33.

149 Dierks 80.

${ }^{150}$ Dierks 80. 
Es ist in den letzten beiden Jahrzehnten viel über diese 'Sozialisationsagenturen' geschrieben worden. Einig war man sich allgemein darüber, daß die Schule bis in die Gegenwart ihre aus der bürgerlichen Erziehungstradition stammenden Grundstrukturen beibehalten hat. Und zweitens, daß fast nur ein, 'bürgerliches' Elternhaus auf eine solche Schule erfolgreich hinerziehen kann (Dem abzuhelfen, entstand ja die letzte Schulreform.) Zugrunde liegt die Tatsache, daß sich mit der Erziehung des Nachwuchses 'in ihrem Sinne' eine herrschende Schicht an der Macht hält."151

Grethe thus wishes to secure her children a respectable position in society by offering them the proper training.

Karl conveys his attitude on the importance of a good education in that he deems it imperative that his children be successful in school in order to maintain their "social status." He has already made up his mind what each child shall become. Robert, being the eldest son, will follow in his father's footsteps and enter into the family business: ". . . Karl folgt mit seinem Ältesten, der ja nun schon vierzehn ist und in die Firma gehen wird. . . "152 For his daughter, Ulla, Karl also has plans: "Kinderärztin kann sie werden, eines Tages, oder Apothekerin."153 Only for the youngest, Walter, does he have no definite plans -- except that he will not help his brother in the family business: "Ob er wohl weiß, daß er nicht in die

151 Dierks 80.

152Kempowski, Aussicht 513.

${ }^{153}$ Kempowski, Aussicht 244. 
Firma kommt, fragt der Vater seinen Sohn, ob er das wohl weiß? Und dieser nickt ernst."154

Education, then, plays a vital role in society for Karl Kempowski, the author's representative of the middle-class. ("Karl, den der Autor selbst als 'Repräsentanten der bürgerlichen Mittelschicht' charakterisiert."155) Since he wants only the best for his three children, he wishes to instill this thinking in them, as well. As through the example of Karl's recognition of the value of education for his children, the author goes to great lengths to outline the principles of education for this period in history. With this next generation of Kempowskis now in school (the children of Karl and Grethe), one can already sense the influences of National Socialist ideology, as well as changes in teaching methods and educational philosophies. Throughout the Kempowski childrens' elementary years, however, teaching methods and ideologies are still heavily influenced by the Reformpädagogik. 156

The time is March 1929 and the eldest Kempowski child, Ulla, is attending school. Ullas class, "so oft es geht," is allowed to take field trips to the countryside. "Bauen Sie die Heimatliebe in den Kindern auf,'" the school director says to the teacher Fräulein

\footnotetext{
${ }^{154}$ Kempowski, Aussicht 408

155I. Schneider in Weibels, 41.

156 Dierks 81.
} 
Schlünz, "' Die Heimat ist das einzige, was wir noch haben!'"157 The children were thus conditioned to contemplate the concept of homeland early on in their educational experiences.

As is also pointed out by Weibels, Fräulein Schlünz is obviously a representative of the Pedagogical Reform Movement158, as the narrator indicates by the comment: "eine Anhängerin der neuen Methode." 159 And she appears to be a product of the Youth Movement: "Sie steuert ebenso erkennbar auf den 'Bund Deutscher Mädel zu."'160 Fräulein Schlünz bases her teaching on the child's needs. One is offered insight into her instructional strategies. They begin -- "vom Kinde her." ${ }^{n 1}$ The inspector of schools reminds her: "'Lassen Sie den Kindern ruhig Zeit,"' and the narrator adds: " . . so was hört ein jeder Lehrer gern. Das Lerntempo muß sich den Kindern anpassen, nicht umgekehrt." ${ }^{n 162}$

Damit wirkt sie im Sinne des pädagogischen Programms der Weimarer Republik, das sich stark an den Idealen der reformpädagogischen Bewegung orientiert, wonach im

157Kempowski, Aussicht 282.

158 Weibels 46.

159Kempowski, Aussicht 233.

${ }^{160}$ Dierks 81.

161 Kempowski, Aussicht 233.

162Kempowski, Aussicht 233. 
Mittelpunkt des Unterrichts nicht der Lehrinhalt, sondern das Interessee des Kindes stehen soll. 163

According to Dierks, this method was meant to bring very positive results: "Alles in allem jedoch ergibt das eine pädagogische Idylle, eine Kindheit wohl auch, in die man sich später wohl intensiv zurücksehnen wird -- was nicht sagt, daß sie nicht 'lebenstüchtig' gemacht hat. ${ }^{164}$

The Montessori-Schule ${ }^{165}$ was one of the driving forces behind these innovative teaching strategies. The school came into being as a reaction against the modernization of society through everincreasingly present technological advances. The bourgoisie, driven by an "innerlichkeitsbetonten Persönlichkeitsideal"166 wanted to protect itself against this "technische Zeitalter"167

Denn aus den Lehren der Montessori sowohl wie denen Berthold Ottos oder Georg Kerschensteiners eignete sich der Erziehungsstil der Mittelschicht nur an, was sich mit den Leistungsanforderungen der Zeit vereinbaren ließ.168

${ }^{163}$ H.J. Schmidt in Weibels, 46-7.

164 Dierks 81.

165 In 1907 Maria Montessori (1870-1952) founded a school for workingclass children in Rome. In addition to being an activist for womens', as well as childrens' rights, she was an educationalist. In her school she strongly encouraged Selbstständigkeit, Selbstbelehrung, Selbstkontrolle and Selbsterziehung. Her innovative teaching methodologies gained her world-wide approval from her colleagues. The Kempowski references "vom Kinde her" are thus allusions to the Montessori method.

166 Dierks 81 .

167 Dierks 81.

${ }^{168}$ Dierks 81 . 
In the same passage in which the the ideal teacher is portrayed, the ideal "Schülerin" is also depicted. Leni Pagels is her name and she represents not only the model pupil, but the model "German" pupil. She idealizes her teacher, whom she views as her leader and role model. (She is also obviously the teacher's pet!). As an example to her peers, she is the one chosen by Fräulein Schlünz to carry the flag on their excursion through the forest. (Note: this is a flag designed by the teacher to represent nature -- it is not the German national flag). "Leni Pagels darf die Fahne tragen, nur Leni Pagels . . . "169 One also senses the national pride felt by the other girls, as noted through the physical description of Leni:

Ihre braunen Beine sind bedeckt von einem Flaum zarter blonder Härchen. Gegen den blauen Himmel muß man dieses Mädchen sehen, wie es im Winde sitzt, neben der kräftigen Lehrerin . . . dann weiß man, daß es in unserm deutschen Vaterland noch gute Säfte gibt. 170

The teacher Fräulein Schlünz also demonstrates exemplary conduct and appearance, not only in that she takes it upon herself to carry out the wishes of the State in terms of what should be taught (i.e., Vaterlandliebe by teaching the students to get in touch with and to respect nature) but she embodies the image of the physically fit as well (later promoted by the Nazis). "Fräulein Schlünz ist eine 
junge sportliche Lehrerin, die gern in den Harz fährt und da herumklettert, im Winter sogar Ski läuft!"171 One thus sees that this young teacher personifies all the ideals of the Reformpädagogik. One also perceives, however, that a transition in teaching methodology is occuring when this junge sportliche Lehrerin is compared with Robert's teacher, Herr Zimmermann.

Robert's teacher at this time, Herr Zimmermann. This teacher employs the opposite teaching tactics than does Fräulein Schlünz. His style is much more regimental. Interesting to note is that he is the administration's representative for the ideal teacher. "Von Lehrerseminaren wird er besucht, weil man seinen Unterricht für vorbildlich hält."172 One sees that the teacher has absolute control and that discipline reigns, when with a simple "Sst!", the children assume the learning position by folding their hands and placing them on top of their desks.

Herr Zimmermann's domineering teaching style is also depicted during a lesson where the pupils are shown a picture of a pig and must then describe what they see, using correct grammar. They are only allowed to respond in complete sentences. Weibels describes the scene:

"Der als vorbildlich geltende Unterricht stellt sich als streng reglementierter Wechsel von Frage und Antwort

${ }^{171}$ Kempowski, Aussicht 232.

172Kempowski, Aussicht 287. 
heraus, wobei der Lehrer nur eine bestimmte von ihm im voraus festgelegte Antwort gelten läßt, alles andere ist falsch."173

The narrator relates the scene:

'Was siehst du auf dem Bilde?' fragt Herr Zimmermann.

'Einen Pferd', antwortet ein Kind.

'Das heißt ein Pferd. Sage noch einmal: Was siehst du auf dem Bild?'

'Ein Pferd.'

'Sprich im ganzen Satz: Ich sehe . . . .'174

If a child responds incorrectly and then proceeds to be openly obstinate, he receives a blow from Herr Zimmermann's pointer. One can deduce that the author does not agree with such rigid teaching tactics, as is evidenced by the statement: "So schreitet der Wissenserwerb bei diesem Lehrer fort, Schritt für Schritt. Hier wird nichts überstürzt."175

The teaching styles of Schlünz and Zimmermann thus do not coincide. Schlünz' teaching style unmistakably stems from the Reformpädagogik and though flexible as a teacher, she appears unrelenting in not wishing to be deterred from carrying out her learned ideologies in the classroom. Zimmerman, on the other hand, represents a different school of thought -- perhaps the embodiment

173 Weibels 47.

174Kempowski, Aussicht 288.

175Kempowski, Aussicht 289. 
of the transitional phase between the Reformpädagogik and that of the Nazis. It is interesting to note that he is the one deemed the exemplary teacher and it is he who is observed by teaching seminars -- not Schlünz! This fact indicates that Zimmermann's style is more representative of the time, rather than Schlünz's, whose may have already been. Due to Kempowski's writing stuyle, one cannot be certain of the exact year represented in these passages. (The beginning of the Schlünz passage is dated 1929 but it is possible that the incidents related could represent a period of several years). One thing the reader can remain sure of, however, is that a transition in teaching methodologies is indeed occurring.

Chapter twelve relates the initial school experiences of the youngest Kempowski child, Walter. The time is the mid-1930's. Kempowski outlines the relevence of this chapter in terms of the theme Erziehung : "Besonders in einem Kapitel des Romans, Schöne Aussicht, wird Erziehung zum alles bewegenden Hauptmotiv, ja zum einzigen Thema: Im Zwölften. In diesem Kapitel wird von Einschulung berichtet und von ersten Schulerlebnissen."176 $\mathrm{He}$ further clarifies that it is not simply to expose the pedagogical movements but to enlighten the reader as to how such teaching ideologies were practiced during the early years of the Nazi regime.

Nur scheinbar geht es dabei um die Gegebenheiten an der St. Georg-Schule in Rostock im Jahre 1935. In 
Wirklichkeit bildet die Einschulung des kleinen Herrn Kempowski nur den Rahmen, den Ansto $B$ dafür, sich einmal gründsätzlich mit den erziehlichen Einflüssen auseinanderzusetzen, denen junge Menschen ausgesetzt waren zu Beginn der Nazizeit. 177

The chapter opens with an elaborate description of the school and its surroundings.

"Die St.-Georg-Schule liegt in der St.- Georgstraße, die genau ein Kilometer lang ist und in den St. Georg -Platz mündet. Sie ist eine von dreizehn Volksschulen in Rostock, eine in roten Ziegeln erbaute Erziehungsburg mit Zinnen und angedeuteten Schießscharten."178

As the author explains, there indeed existed a school by that name. Only the Schießscharten were invented in order to suggest that the school had a means of warding off intruders from the "outside". Kempowski thus likens the school to a Burg (as evidenced by the description). It functions to shelter the children from "outside" influences, while the teachers exert their influence from within.

Damit soll gezeigt werden: Was hier geschieht, findet unter aquariumähnlichem Ausschluß der Öffentlichkeit statt, es hat mit dem Leben draußen nicht viel zu tun. Die Burgmauern wehren einerseits äußere Einflüsse von den Schülern, so weit es geht, ab, sie halten die Kinder gleichzeitig wie in einem Zuchthaus gefangen, damit sie

177Kempowski, "Erziehung" 2.

178Kempowski, Aussicht 401. 
sich den massiven pädagogischen Einwirkungen der Lehrer nicht entziehen können. ${ }^{179}$

Of course this system was not fool-proof, but it worked in theory. The "outside world" penetrated the barrier in spite of efforts to keep it out. One such example is the education the younger boys receive by reading what the older boys have written the bathroom walls. This free education the author terms as "... eine Art Aufklärungsunterricht . . ".180 This learning method he thus concedes is "...exklusiv, einfach und wesentlich wirksamer als in modernem Sexualunterricht: in den Lehrplänen war er damals nicht vorgesehen."181

The chapter then continues with a detailed description of the school:

In jeder Klasse hängt ein Bild in Eiche gerahmt. Es gehört zur Erstaustattung dieser Schule und stellt einen Pflüger dar, hinter dem Krähen herfliegen, oder einen Ritter, der nach getaner Arbeit seiner Burg zustrebt. Neben der Tür, direkt unter dem Lichtschalter, den die Schüler nicht betätigen dürfen wegen der Gefahr, die damit verbunden ist, hängt außerdem ein kleines Hitlerbild, in Art einer Federzeichnung mit dem flüchtigen Namenzug des Reichskanzlers darunter ${ }^{182}$

179 Kempowski, "Erziehung" 3.

180Kempowski, "Erziehung" 3.

181 Kempowski, "Erziehung" 3.

182Kempowski, Aussicht 404. 
The images depicted by such pictures could show: 1) how closelytied a farmer is to his land and to nature; 2) hard work is noble; and 3) the image of the knight suggests ties to Germany's past -- the "honor" of the nobility. All possibilities suggest that the motive behind the hanging of these particular pictures was to impress a certain way of thinking into the minds of the children. German ideals were thus inadvertently working their way into the childrens' subconscious.

The way in which the author introduces the picture of Hitler is very matter-of-fact. He expresses no surprise at it being there and makes no derogatory remarks. It is simply there and it is understood that there is where it belongs. The Hitler picture functions as a constant reminder to the children of who their leader is.

The Lehrkörper in this school is slowly introduced. There are hints that reality is not always as it may appear.

In dieser Schule, in der es natürlich keine Lehrerinnen gibt, herrscht ein strenges Regiment. Das ist nun mal so. Wahre Schreckens-menschen gibt es unter den Pädagogen. Es gibt aber auch träge Existenzen, die nach außen den Anschein äußerster Strenge aufrechterhalten, nach innen jedoch -- leben und leben lassen. ${ }^{183}$

This quote prepares the reader to meet teachers who represent both schools of thought. The representatives include Herr Jonas and Herr 
Hagedorn. "Bei Lehrer Jonas . . . kommt das phantasiebildende Geschichtenerzählen sehr zu seinem Recht und weniger das Lernen."184 (It is this teacher that the author personally identifies with the most.) Hagedorn, on the other hand, embodies the opposite school of thought concerning teacher types. His self-assuredness is evident, as Dierks points out: 'Bei mir sind sie ganz frei!' kann sich auch sein Kollege Hagedorn rühmen, Vollblutpädagoge mit Schillerkragen, Vegetarier und Bienenzüchter."185

Herr Jonas is not the authoritarian type. On the first day of school, when all other teachers have their first lesson well under way as well as under control, Jonas is still standing in the hallway trying to reassure distraught mothers that their children will be safe in his care. Naturally the children, alone in the classroom, become rambunctious. The narrator describes the scene: "Clowns tun sich hervor, die sich 'was zeigen', lauter wird's und immer lauter ...."186 Finally, disturbed by the noise, Jonas' colleagues disapprovingly inspect the situation. "Kollegen gucken heraus, die ihren Abc-Schützen schon längst die fällige Geschichte von 'Heiner im Storchennest' erzählt haben und bereits mit Volldampf auf den ersten Buchstaben zusteuern." 187 Their attitude toward their

184 Dierks 82.

185 Dierks 82.

186Kempowski, Aussicht 406.

187 Kempowski, Aussicht 406. 
colleague is then reflected: "So geht das aber nicht, Herr Kollege."188 This comment suggests that Jonas' seemingly relaxed teaching approach did not coincide with the current trend.

Like Fräulein Schlünz, Jonas begins each day by allowing the children to tell stories. The course of the day's lessons, then, is oriented according to what the children have narrated. That which comes across as "laziness" and "unpreparedness" in Lehrer Jonas could indicate, on the one hand, that he is not suited for the teaching profession. Or, it is the author's hint that Jonas is actually a role model for the "ideal" teacher -- one who is a self-critic and not overly self-confident. As Weibels elucidates: "Jonas erscheint in der Darstellung durch den Autor relativ hilflos, unfertig und als ein Mensch, der ständig an seiner Eignung für den Lehr-Beruf zweifelt."189 (His insecurities and/or inabilities as a teacher, however, in no way threaten his position, for he has Beziehungen.) His laissez-faire attitude toward teaching is reflected in his first lesson on the first day of school:

Lehrer Jonas sitzt auf dem Katheder und sieht mal hierhin und mal dorthin. Vor sich hat er das Klassenbuch, in das er jetzt einschreibt 'Zuckertüten kneten'. Dann faltet er die Hände unterm Kinn[,] denkt an einen schönen Sommerabend auf dem Lande und guckt sich die Kinder an. ${ }^{190}$

188Kempowski, Aussicht 406.

189 Weibels 48.

190Kempowski, Aussicht 407. 
$\mathrm{He}$ is obviously not planning his next (or first) move, nor is he contemplating teaching strategies with which to enthrall his young audience. Rather, he is waiting for the children to initiate the action. He does not have to wait long, however: "'Wann liehrt wi denn nu datt schriewen?' frage einer".191 And with that Jonas is awakened from his trance and the ice has been broken. Other children then become bolder and have no fear of approaching the teacher. The first task is finally underway. The children are to make clay models of their Zuckertüten. "Und nun kommen schon die ersten Kinder nach vorn -- aus ist's mit der Beschaulichkeit --, sie zeigen ihre geknetete Zuckertüte vor, graue, grüne, gelbe oder rote, mit Inhalt in der gleichen Farbe."192 The child, however, who decides to be creative and use a variety of colors, is not singled out, nor does Jonas make the other children feel inferior for not being original.

"Und Jonas sagt nicht: 'Seht mal, wie schön bunt der seine Zuckertüte geknetet hat, eure Zuckertüten sind aber langweilig, sondern er versteht das, daß die andern Kinder nur eine einzige Farbe anbrechen wollten, er hätte das genauso gemacht . . .."193

${ }^{191}$ Kempowski, Aussicht 407.

192Kempowski, Aussicht 407.

193Kempowski, Aussicht 407. 
Herr Hagedorn, on the other hand, tries to do everything by the book. He is concerned that he do his job correctly but above all, he is concerned that others recognize just how good he is: "Hagedorn macht einen sicheren, selbst-bewußten und von sich und seinem Können überzeugten Eindruck."194

\begin{abstract}
"Herr Hagedorn handhabt nicht nur den Lehrstoff virtuous, er dreht auch über den vorgeschriebenen Strukturen der Unterrichtsstunde seine Pirouetten, und er möchte, daß man merkt, daß er das kann, und ihn für einen tüchtigen Lehrer hält."195
\end{abstract}

Hagedorn, unlike his colleague Jonas, does not allow the children so much time to tell of their own experiences. "Ich habe die Kinder immer schon nach fünf Minuten,"196 he boasts. As Weibels points out, haben in this sense means kontrollieren. ${ }^{197}$ Hagedorn (unlike Jonas), however, is respected by his colleagues. The narrator enlightens the reader to their opinions:

Er ist immer gut vorbereitet, weiß, wie man eine Stunde 'baut', auch ohne die Formalstufen. Ein netter, freundlicher Mensch, den seine Schüler lieben, der derartig in seinem Beruf aufgeht, daß sie inn sogar

${ }^{194}$ Weibels 48.

195Kempowski, "Erziehung" 7.

196Kempowski, Aussicht 409.

197 Weibels 48. 
vergessen werden, wenn sie eines Tages ins Leben hinaustreten." 198

As indicated by the opinions of the students, however, this good impression of their teacher that they are left with will not necessarily be a lasting one. '"Da war doch so ein netter Lehrer', denken die ehemaligen Schüler später. Geblieben ist nur ein Bild vager Freundlichkeit, ein lichtes, leichtes Bild ohne Kontur."199

Hagedorn is constantly concerned about peer as well as authority approval. Jonas, one the other hand, is not troubled by it. Since he has Beziehungen, he knows his job is secure. He thus responds accordingly, teaching according to his own principles and not those dictated by others. With that the reader is left to draw his own conclusions as to which teaching style is the most effective. As indicated by the responses of their colleagues, Hagedorn is the one who best conforms to the accepted practices of the day. One must keep in mind, however, that the educational system was undergoing a transitional phase. The Nazis had not yet completely taken over -their presence, nonetheless, was strongly felt.

198Kempowski, Aussicht 405.

199Kempowski, Aussicht 405. 


\section{TADELLÖSER \& WOLFF (1939-1945)}

The author's second publication and fourth novel of the series bears the title, Tadellöser \& Wolff. As Kempowski reveals, "Dieser Titel war es, unter anderem, der das Buch sofort bekannt machte."200 He explains that when he cites the title, he is actually quoting his father. It originates from the name of a cigar company from which his father received crates of free samples each year. As he tried them, the good ones he labelled "tadellöser" from "tadellos," expressing his approval and distinguishing them as top quality. Since Loeser \& Wolff was a widely-publicized advertisement in its day, the pun was easily discernable. Karl Kempowski thus labelled anything he found of exceptional quality or pleasing to him as "Tadellöser \& Wolff."

(As can be conjectured by the title, the novel contains many such word games.) Kempowski hints that given the political-historical time of the novel -- beginning with the outbreak of the war in 1939 and continuing through the spring of 1945 when the Russians march in to Rostock to begin their occupation of the city -- the title may convey a hidden message:

Vielleicht steckt unter dem saloppen Slogan-Titel noch eine tiefere Bedeutung. Ich will nicht auf eine ins Humane weiserende Verlängerung hinaus, 'Tadellöser \& Goethe' -- sondern ich meine, daß

200Kempowski, "Iadellöser \& Wolff", unpublished essay, 2. 
dieser Titel einstimmen sollte auf ein Buch, das von tadellosen Saubermännern und Wölfen handelt, die man sich im Schafspelz denken kann.201

The publics' early intrigue with the novel was thus, in part, due to the unique title.

Set in Rostock in 1939, the story begins when the central figure, Walter Kempowski, is ten years old and Nazism is at its heighth. The young Walter narrates the story in the first person, painstakingly and vividly portraying his surroundings -- often down to the minutest detail. Typical of Kempowski's style, his characters display very little emotion and sentiment. Irony assumes its role and serves to distance the reader from the tragedies of human suffering.

The novel drew a variety of reactions from the critics. These reactions, "einander wiedersprechend", ranged from ". . . einer bruchstückhaften Realität, Erinnerungstrümmern ohne Totalität einerseits" to a ". . . fast lückenlosen Rekonstruktion von Wirklichkeit andererseits . . 202 Also, as the author makes reference to, this is the novel which best exemplifies the use of the Zettelkasten, giving the reader the impression of leafing through a photo album. "Tadellöser \& Wolff hat diesen Schnappschußstil, der Ähnlichkeit mit einem Fotoalbum aufweist . . ."203 It is on these

\author{
201 Kempowski, "Tadellöser" 3. \\ 202 Mecklenburg. \\ 203Hage, "Glücksfall" 189.
}


grounds that Kempowski's critics base their fault-finding campain that the author's intention is to "play down" the Nazi past. The author, however, has his own interpretation of the literary technique employed in the novel. Mecklengurg cites him:

In Iadellöser \& Wolff sei das Harmlose die 'Verpackung' für das Schlimme, die Idylle für das Grauenhafte, wenn gleich eine oberflächliche Rezeption des Romans sein Mißbrauch als 'Witzbuch' dafür blind bleibe."204

In the author's opinion, to label the novel a Witzbuch is to misinterpret it's intended message.

Kempowski also defends his objective for narrating the story from the perspective of a boy:

“. . . ich habe Iadellöser \& Wolff doch wohl aus der Perspektive des Zehn - bis Fünfzehnjährigen geschrieben, und der hat sich mehr um Jazzplatten gekümmert als um das Schreckliche -- weil er das auch nicht erfuhr als Jugendlicher, das hielt man ja von ihm ab."205

It is imperative that the reader recognize Kempowski's attempt to portray the past as it occurred. Mecklenburg outlines the historic years encompassed in the novel: “. . . von den Monaten vor dem deutschen Überfall auf Polen bis zum Tag des Einmarsches

204 Mecklenburg 19.

205 Hage, "Glücksfall" 188. 
sowjetiwscher Truppen in Rostock."206 Using historical events as a backdrop and point of reference, Kempowski's objective is to portray the everyday life of a typical middle-class family.

In der locker gefügten Kapitelreihe bildet die Zeitgeschichte nur den Hintergrund, der einige Einschnitte markiert: Kriegsausbruch, Einberufung des Vaters, Bombardierung, Zusammenbruch. Die Hauptthemen, unter denen das Material kapitelweise zusammengestellt ist, geben doch typische Familienereignisse und Jugenderlebnisse in bürgerlicher Welt her: Umzug und Ferienreise, Tod, Hochzeit, Krankheit von Angehörigen, Schulwechsel, Klavierstunde, Nachhilfunterricht, Spiele und Streiche, Freundschaften, Besuche. Faschismus und Krieg liefern dagegen nur wenige gesonderte Themen, an erster Stelle Walters Dienst in der Hitlerjugend vom Pimpf bis zu Einberufung, Kasernierung und Kriegseinsatz.207

The focus, then, is on the Alltagsleben which offers the reader a look at history from an entirely different perspective. By portraying the past in this manner, without comment or hindsight from the narrator's perspective, Kempowski is, in essence, allowing history to speak for itself. His method of continuously shifting from scene to scene without necessarily updating the reader with graphic descriptions of the historical situations in each instance, helped lead to to the label "pointillistic' -- referring to the author's portrayal of history. Dierks stresses, however, as does the author 
himself, that it is the task of the reader to fill in the gaps. "Diese Zäsuren des Kriegsverlaufs und auch die staatlichen Organisationen werden in Tadellöser \& Wolff unerklärt als bekannt vorausgesetzt."208

This novel was written at the beginning of the author's career. One detects a certain lack of sophistocation evident in the later novels. As Dierks points out, one notices the author's tendency to rely on his Zettelkasten more frequently. The origin of such source material in certain passages is unmistakable. Dierks cites the following example:

\footnotetext{
"Tagelang fuhren wir Straßenbahn.

'Pfunds - S - pass, sagte Ulli.

Die wippten, wenn sie angesaust kamen.

Ist's die Brille, geh zu Krille.

Mit der 11 zum neuen Friedhof."209
}

The initial association that the reader must draw here, as Dierks explains, is that the S-Bahn teeters at high speeds. Secondly, one must recognize the Billboard advertisement seen by the passengers as the train whips by.210 (Such a passage could have been inspired simply by the author having located an original advertisement.)

\footnotetext{
208 Dierks 93.

209 Kempowski, Iadellöser 328.

210 Dierks 98.
} 
A further example is cited to elucidate Kempowski's use of the Zettelkasten, this time from the headline of a newspaper: "Herr Woldemann warf den 'Rostocker Anzeiger' auf den Tisch: 'Exeter mit schwerer Wirkung bombardiert!' und langte sich noch eine Weinflasche."211 The historical reference is offered, but recognizable only for those who are well acquainted with the history of the war, claims Dierks:

"Das Zitat zeigt in der Geschichte des Krieges . . . die letzten deutschen Luftgroßangriffe auf England an, die bereits in der Wendephase des Krieges liegen. Dadurch wird für den historisch Erfahrenen oder Kundigen das Geschehen zeitlich genau bestimmt."212

The reader must therefore be aware of the historical references and be able to place the incident in the proper historical perspective.

From the opening pages of the novel the historical framework is slowly layed. In this montage of history, one gets bits and pieces of information which point to the signs of the times. Such pointillistic "photo-album" inferences hint at the family's standard of living. Ulla, with her Agfa-Box photographs the family: "Die Mutter im Pelerinenkleid, Robert beim Segeln und ich [Walter] im Hamburger Anzug. Vater sogar als SA-Mann unter einer Birke."213 It appears,

211 Kempowski, Iadellöser 159.

212Dierks 99-100.

213Kempowski, Iadellöser 15. 
therefore, that the Kempowski family is able to lead a comfortable life and one senses that the national socialist influences have worked their way into in all facets of family life. It is already a major step for the family that the father, "Körling," voluntarily enlisted -- his sense of duty to serve his country carrying over from his experiences in the First World War. Another hint of the ubiquitious influence of the national socialists is contained in this example: "Nach dem Kino ging es ins Lesecafé. Dort saßen Freunde vom Jachtklub. Juden unerwünscht."214 And in Karl's office hang the following pictures: “. . . an der Wand Hitler, Hindenburg und Bismarck übereinander."215 Times have indeed changed.

At home the Kempowski children are brought up according to standards and expectations for members of their parent's social class. (It appears that by this time Karl and Grethe have resolved their disputes about how to raise their children -- they know their respective roles.) The standards and values held by members of the German middle-class between the years 1939-1945 are upheld not only at home but in school as well. Weibels outlines these standards for conduct:

- eine positive Einstellung zur Familie und das Festhalten an Traditionen und Gewohnheiten.

- Pünktlichkeit und Pflichterfüllung,

- Ordnung,

214Kempowski, Tadellöser 28.

215Kempowski, Iadellöser 38. 
- ein ausgeprägtes Standesbewußtsein und eine konservative politische Gesinnung,

- der sorgfältige Umgang mit Geld,

- eine fehlende sexuelle Aufklärung sowie

- ein . . . formalisiertes religiöses Verhalten. ${ }^{216}$

Kempowski's characters are obviously moulded by such behavioral expectations as society demands of them.

Walter's school experiences are not as vividly depicted as in Schöne Aussicht. The montage-style of this novel leaves many more holes to be filled by the reader. Walter has succeeded in being accepted into the Gymnasium. It appears, however, that "connections" had the most influence in the decision-making, since his test scores were not among the highest. "Aber selbstverständlich wurde ich aufgenommen. lch war doch der Sohn von 'Körling.'"217

Walter comments about his first impressions of teachers Hannes and Kniese. They typify how he, the narrator, perceives the world about him -- through the eyes of a ten-year-old. As the story opens, Walter finds out that he will have one of two teachers. He describes them: "ein kleiner dicker mit Glatze und ein größerer finsterer mit einem Kopf wie ein Uhu."218 He naturally gets the latter of the two, whom he would rather have avoided. This teacher is Hannes. The

216 Weibels 52 .

217Kempowski, Iadellöser 38.

218 Kempowski, Iadellöser 38. 
curriculum seems to have included everything! "Bei Hannes hatten wir dann alles, inklusive Religion."219 Dierks offers insight into the personality make-up of the teaching staff:

Noch einmal werden Lehrer vorgeführt, Käuze und Karrieristen, wie sie das deutsche Gymnasium offenbar traditionell hervorgebracht hat. Dem Nationalsozialismus stehen sie meist nicht fern, teils aus eben kauzigen Gründen . . . , aber doch vor allem, weil er ihnen die Hoffnung auf nationale Größe einzulösen schien. Verglichen mit der stark 'reformpädagogisch' geprägten Grundschule ist dies Gymnasium übrigens nicht human, hinter der -- aus der Schülerperspektive erfaßten -Komik wird sein Charakter als Drill und Lernschule sehr wohl deutlich ....220

Though perhaps for various reasons, all teachers appear to be strongly affiliated with the party. Weibels characterizes Hannes as an "überzeugter Nationalsozialist"221 who time and again tells of "Gotterleben im Kriege."222 Hannes, like other teachers, tries to instill national socialistic thinking in the children. Weibels further illustrates that the teacher attempts to convince the boys that they should be proud of the times they are living in -- that they have all

219Kempowski, Iadellöser 39.

220 Dierks 91.

221 Weibels 66.

222Kempowski, Iadellöser 39. 
the more reason to do well in school -- and this will correspondingly help to strengthen their country.223

Perhaps one of the most exemplary demonstrations of Hanne's devotion to the Vaterland is illustrated during a commemorate ceremony in honor of Peule -- a former teacher who has lost his life serving his country. The ceremony takes place in the school gymnasium. During the course of his speech Hannes once again takes the opportunity to lecture on serving one's country: "Dann sprach er vom Gotterleben im Kriege."224 His speech is so moving that soon the entire audience is on its feet. "Alles sprang auf. Auch die Lehrer, die dicken und die dünnen, die mit und die ohne Parteiabzeichen, wußten nicht warum."225 One of them, however, as the narrator notices, is especially patriotic. "Vor mir, der Eckhoff, der stand besonders gerade, der stand für Deutschland."226 Eventually the director leads everyone in the Deutschlandlied. All stand at attention with the Heil Hitler salute. Walter participates but not necessarily out of a sense of devotion for the fatherland. Rather, he merely goes along with the rest. As the following comment illustrates, his heart was not in it: "Wir mußten die ganze

\author{
223 Weibels 66. \\ 224Kempowski, Iadellöser 123. \\ 225Kempowski, Iadellöser 123-4. \\ 226Kempowski, Iadellöser 124.
}


Zeit grüßen, mit schwerer werdenem Arm. Schließlich stützte man sich auf die Schulter des Vordermannes."227

During this same assembly the school director takes the opportunity to deliver announcements. One sees how deeply the national socialist influence infiltrated the schools. There have been some policy changes. The reader remembers that a generation earlier Karl was photographed with his classmates -- all wearing Schülermützen. Now, however, "Das Tragen von Schülermützen sei verboten." 228 The director then has a second announcement: " . . da dürfe es nicht mehr 'Verbesserung', sondern 'Berichtigung' heißen. Das sei schlechtes Deutsch."229 The implementation of this "new" vocabulary thus began to a large extent within the school system.

In keeping with the national socialist Weltanschauung, church and religion no longer play a role in the classroom. Hannes reveals his stance on the matter by singling out Walter as a Neanderthal example for being able to wiggle his ears!230

"Bei Hannes hatten wir leider nur noch Biologie. Die Urzelle. Irgendwo müsse das Leben ja herkommen sein. $\mathrm{Da}$ ich mit den Ohren wackeln konnte, wurde ich als Art

227Kempowski, Iadellöser 124.

228Kempowski, Iadellöser 124.

229Kempowski, Iadellöser 124.

230 Weibels 67. 
Neanderthaler vorgestellt. Das habe sich aus Schlamm entwickelt."231

Another significant change to the curriculum due to national socialist influences was that music was no longer viewed as playing a vital role in the develoment of a child. The narrator attests to this fact: "Die Musikstunden wurden gekürzt. Laß doch der Jugend, der Jugend, der Jugend ihren Lauf . . ."232 (One remembers that the formal addition of music to the curriculum came about as a result of the Reformpädagogik. )

Discipline is still strongly enforced. Dr. Finck, whom they call "Liesing", " . . . ließ sich nichts vormachen."233 Walter narrates how one student had to write the name "Liesing" one thousand times for merely having said, "Liesing kommt."234 And if one did not know the answer, he received a pinch on the arm. "Was glaubst du, wie das hilft!"235 the narrator adds.

Liesing also finds it difficult to tolerate Walter's teen-age vanity -- his impudence for wearing his father's tie and carrying his comb with him, constantly fussing with his hair. Liesing's attitude

231 Kempowski, Iadellöser 125.

232Kempowski, Iadellöser 125.

${ }^{233}$ Kempowski, Iadellöser 125.

234Kempowski, Tadellöser 125.

235Kempowski, Iadellöser 125. 
toward the tie is conveyed: "Mir schnipste Liesing die Krawatte aus der Jacke. 'Ei der feine Pinkel, kommt hier mit'm Schlips zur Schule'"236 Walter is then further degraded by the teacher for having his hair too long. (Walter is constantly persecuted for his long hair - a symbol of teen-age defiance and rebellion against authority in general). Walter is asked by Liesing whether he has something against barbers or whether it is simply because his father cannot afford to pay for the haircut. Liesing gets revenge. "Meinen Kamm pickte er mit zwei Fingern und warf inn aus dem Fenster. 'Altes Ferkel.' Wischte sich die Finger ab. 'Äh!"237

Life was thus difficult for the nonconformist. The system did not allow room for individuality. In school, as well as in the real world, peer pressure (such as the above examples provide), in addition to coercion from authority figures (teachers included) helped ensure the success of the national socialist movement. As Kempowski's examples illustrate, not all individuals necessarily wanted to conform. But the future was unsure for those who chose not to. The historical snapshots provided in Tadellöser \& Wolff help one to understand not only how the school system functioned during the Hitler years, but are also a reflection of how society functioned, in general.

236Kempowski, Iadellöser 126.

237Kempowski, Iadellöser 126. 


\section{CHAPTER $V$}

\section{SUMMARY}

When approaching a study of the Familienchronik from a critical point of view, one must bear in mind that Kempowski's novels not only extend half a century, but that there is a time span of thirteen years between the publication of the first and last volumes. Therefore it is oftentimes difficult to "generalize" critics' statements and refer to the six novels as one piece of work, even though they are collectively termed the Familienchronik. That is to say, what pertains to one novel specifically may not necessarily apply to the next. Each is individual and unique. For example, one can classify Iadellöser \& Wolff as a "montage," as "pointillistic," as solely comprised of the Erinnerungssplitter: one could ascertain that Aus aroßer Zeit is not historical since the author did not live the times represented; or one could assert, as does one critic, Stanley, that Ein Kapitel für sich is a Bildungsroman in the tradition of Goethe. Each statement is a partial truth but deals solely to one select novel of the series. One must thus take precautions not to over-generalize.

One common characteristic of the Familienchronik regardless of Kempowski's manner of portrayal is that his message remains 
consistent -- to expose history from the perspective of history in the making. Kempowski tries to remain as true to reality as possible, although he himself admits -- it is impossible to recreate history. ${ }^{238}$ The author makes many claims in various interviews and essays that a certain information (i.e. specific references and historical accounts) is evident in the Familienchronik -- that it is there for the reader. It then becomes the task of the reader to take special care to perceive this information. If the novels are read accordingly, then one can say that the inherent historicity speaks for itself. One thus need not rely on the author's own account of what he proclaims to be the intended message.

Notwithstanding Kempowski's reference to the content of the Familienchronik, one problem has been that some critics are quick to point out that these references are too subtle and too seldom used. However, to state that Kempowski's works are not historical (simply because certain readers do not always grasp these references as offered) is to indicate that one is not familiar with Kempowski's works. As has been evidenced, one must know how to read the Familienchronik; one must understand that the author has a specific intent for portraying the historical situation in the manner that he does, and that a certain responsibility in recognizing these references belongs to the reader. Kempowski suggests that Erziehung is the one theme that extends throughout the entire 
Familienchronik. It is a topic to which he personally feels special attention should be devoted. The novel Schöne Aussicht, in particular, sheds light on the German educational system and its philosophies. Kempowski wishes to suggest that a nation's educational system plays a role in determining its history. In specific passages, the author is successful in providing the reader with first hand knowledge of how prototype teachers attempted to apply the methodologies of the educational trends of their day. 


\section{LIST OF WORKS CONSULTED}

Alfs, Günther. "Genause war es_._.". Oldenburg: Heinz Holzberg Verlag, 1982.

Allen, James Smith. "History and the Novel: Mentalité in Modern Popular fiction." History and Theory. 22.3 (1983): 237-252.

Bason, Cecilia Hatrick. Study of the Homeland and Civilization in the Elementary Schools of Germany. New York: Bureau of Publications Teachers College, Columbia University, 1937.

Brockhaus, Henrich. "Walter Kempowski: Zeit- und KulturGeschichte aus dem Zettelkasten." Proceedings of the Pacic Northwest Council on Foreign Languages 27, ii (1976) : 22-24.

Cowart, David. History and the Contemporary Novel. Carbondale: Southern Illinois University Press, 1989.

Dierks, Manfred. Autor-Text-Leser: Walter Kempowski. München: Francke Verlag, 1981.

---. Walter Kempowski. München: Verlage C.H. Beck und edition text + kritik, 1984.

Drewitz, Ingeborg, "Prosa aus dem Zettelkasten." Neue Bundschau 84.1 (1973): 171-75.

Goldman, Lucien. Iowards a Sociology of the Novel. trans. Alan Sheridan. London: Tavistock Publications Limited, 1975.

Görtz, Franz Josef. "Walter Kempowski als Historiker." Akzente 20 (1973) : 243-54.

Hage, Volker. "Eine Art Gedächnis Training: Ein Interview." Akzente 19.4 (1972) : 340-49. 
Hage, Volker. "Der Erfolg ist ein Glücksfall" (Interview, August 1981)" in Die Wiederkehr eines Erzählers: Neve deutsche Literatur der siebziger Jahre. Frankfurt/Main: Verlag Ullstein GmbH, 1982.

Jarausch, Konrad H. Students, Society and Politics in Imperial Germany. Princeton: Princeton University Press, 1982.

Kane, B.M. "Scenes from Family Life: The Novels of Walter Kempowski." German Life \& Letters 28 (1974-75) : 418-26.

Karasek, Hellmuth. "Der Erabschreiber." Der Spiegel 15 Jan. 1990: 173-82.

Kempowski, Walter. Aus Großer Zeit. Hamburg: Albrecht Knaus Verlag, 1978.

---. "Aus großer Zeit - Graal I, S160-170 und Graal II, S242-258: ein Vergleich." Unpublished essay, 1985.

--. "Die Entfesselungskunst." Unpublished essay.

---. "Glück am Wege: Über die Quellen und deren Verwertung." Unpublished essay, 1983.

--- Haben Sie davon gewußt?. Hamburg: Albrecht Knaus Verlag, 1979.

---. "Die Harzreise: Über Form, Inhalt und Quellen." Unpublished essay. Herbst 1983.

---. Herzlich Willkommen. München: Albrecht Knaus Verlag, 1984.

--.. "Herzlich Willkommen: Woher der Titel." Unpublished essay, 30. Juni 1984.

--.. "Der historische Teppich." Unpublished essay. (published in Bösenblatt für den deutschen Buchhandel. 41 Frankfurt (1985) 770-774). 
---. Immer so durchgemogelt: Erinnerungen an unsere Schulzeit. München: Hanser Verlag, 1974.

---. "Immer so durchgemogelt." Unpublished essay, August 1984.

---. Ein Kapitel für sich. Hamburg: Albrecht Knaus Verlag, 1978.

--- "Ein Kapitel für sich: Anmerkungen zu einem Film." Unpublished essay.

---. "Der Kirchgang." Unpublished essay.

--.. "Klein Winzigerode." Unpublished essay, August, 1984.

---. "Mangelndes Verständnis." Unpublished essay, April 1983.

---. "Marsch an die Front: Betrachtungen über das 31. Kapitel des Romans Aus großer Zeit." Unpublished essay.

-.- "Nach Fünfundvierzig: Aus der Biographie von Margarethe Kempowski," (Oktober 1966 auf Tonband gesprochen). Unpublished essay.

---. "Ostern in Locarno." Unpublished essay.

---. "Randfiguren: Kleinbiografien in der Chronik." Unpublished essay.

---. "Die Rede des Direktors: Das 10. Kapitel." Unpublished essay.

---. "Das Ruderboot: Ein Beispiel für die Beteilung des Unbewußten an einem literarischen Prozeß." Unpublished essay, February 9, 1983. (published in Seiltanz auf festen Versesfüßen: Neun Auteren der Marburger Universität. Ed. Wilhelm Solms (Marburger Literaturtage, vol 2). Marburg, 1987: 43-56).

--- Schöne Aussicht. Hamburg: Albrecht Knaus Veriag, 1981.

--- Iadellöser \& Wolff: ein bürgerlicher Roman. Hamburg: Albrecht Knaus Verlag, 1980. 
---. "Iadellöser \& Wolff: Der Anfang des ersten Kapitels." Unpublished essay.

-.- "Über die Allgegenwart von Erziehung." Unpublished essay.

--.. "Der Umzug." Unpublished essay.

--. Uns geht's ia noch gold: Roman einer Familie. Hamburg: Albrecht Knaus Verlag, 1978.

---. "Von der Auferweckung der Bilder." Unpublished essay.

Kneller, George Frederick. The Educational Philosophy of National Socialism. New Haven: Yale University Press, 1941.

Lämmert, Eberhard, "Geschichte ist ein Entwurf: Die neue Glaubwürdigkeit des Erzählens in der Geschichtschreibung und im Roman." The German Quarterly 63.1 (1990): 5-18.

Lawson, Robert Frederick. Reform of the West German School System. 1945-1962. Diss. Ann Arbor: Malloy Lithoprinting, Inc, 1965.

Lewalski, Barbara Kiefer. "Historical Scholarship." Introduction to Scholarship in Modern Lanquages and Literatures. Ed. Joseph Gibaldi. New York: The Modern Language Association of America, 1981.

Lindegren, Alina M. Germany Revisited: Education in the Federal Republic. Washington: United States Government Printing Office, 1957.

Mecklengurg, Norbert, "Faschismus und Altag in deutscher Gegenwartsprosa. Kempowski und andere." Gegenwartsliteratur und Drittes Reich. Ed. Hans Wagener. Stuttgart: Philipp Reclam jun., 1977.

Nehring, Alfried, "Endlich mit der Marienkirche . . . ," (Interview with Walter Kempowski, 1990): 1-9. 
Roessler, Wilhelm. Die Entstehung des modernen Erziehungswesens in Deutschland. Stuttgart: W. Kohlhammer Verlag, 1961.

Romanos, Christos S. Poetics of a Fictional Historian. New York: Peter Lang, 1985.

Roth, Leo. Handlexikon zur Erziehungswissenschaft. Ed. Leo Roth. München: Franz Ehrenwirth Verlag, 1976.

Rothmann, Kurt. "Walter Kempowski." Deutschsprachige Schriftsteller seit 1945 in Einzeldarstellungen. Stuttgart: Philipp Reclam jun., 1985.

Solberg, Susanne. "Kempowski: Ich bin kein Hochstapler." Kultur Express Donnerstag, 11. Januar 1990: 14.

Stanley, Patricia Haas. "An Examination of Walter Kempowskis, Ein Kapitel für sich." South Atlantic Review 47 (1982) : 38-50.

Stark, Gary D. "Vom Nutzen und Nachteil der Literatur für die Geschichtswissenschaft: A Historian's View." The German Quarterly 63.1 (1990): 19-31.

von Waltershausen, Ilo and Margit. "Interview- Walter Kempowski." Inter Nationes Kultureller Tonbanddienst. Order number 37183.

Wahrig, Gerhard. Wahrig Deutsches Wörterbuch. München: Mosaik Verlag GMBH, 1986-7, 438.

Weber, Dietrich. "Walter Kempowski." Deutsche Literatur der Gegenwart in Einzeldarstellung. Ed. Dietrich Weber. Vol. III. Stuttgart: Alfred Kröner Verlag, 1983: 278-96.

Wellerhoff, Dieter. Der Roman und die Erfahrbarkeit der Welt. Köln: Kiepenheuer \& Witsch, 1988.

White, Hayden. "The Historical Text as Literary Artifact." Critical Theory Since 1965. Ed. Hazard Adams and Leroy Searle. Tallahassee: University Presses of Florida, 1989. 
Wieser, Harald. "Der Abschreiber." Stern Magazin. 11 Jan. 1990: 29-34. 